\title{
Characterization of the Transient Response of the ILS with One Module Installed to Heatup Changes in Power Level and Cooldown
}

K. G. Condie

C. M. Stoots

J. E. O'Brien

J.S. Herring

December 2007

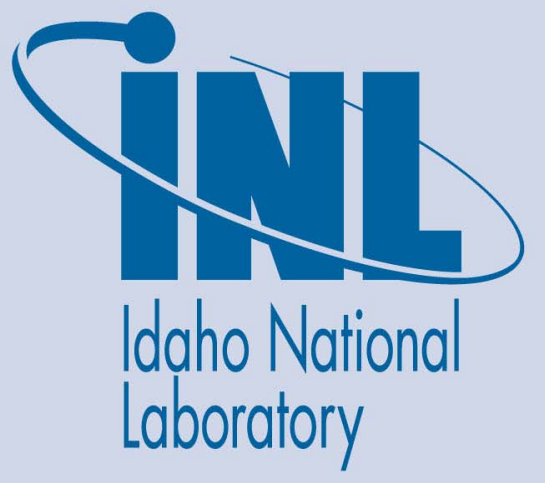

The INL is a U.S. Department of Energy National Laboratory operated by Battelle Energy Alliance 
INL/EXT-07-13626

\title{
Characterization of the Transient Response of the ILS with One Module Installed to Heatup Changes in Power Level and Cooldown
}
K. G. Condie
C. M. Stoots
J. E. O'Brien
J.S. Herring

December 2007

\begin{abstract}
Idaho National Laboratory
Idaho Falls, Idaho 83415
\end{abstract}

Prepared for the

U.S. Department of Energy

Office of Nuclear Energy

Under DOE Idaho Operations Office

Contract DE-AC07-05ID14517 


\section{ABSTRACT}

This report provides documentation of the initial startup and testing of the first electrolysis module in the Idaho National Laboratory (INL) High Temperature Steam Electrolysis Integrated Laboratory Scale (ILS) facility. Initial shakedown testing of the INL ILS experimental facility commenced on August 22, 2007. This fulfilled a DOE Level 2 milestone. Heatup of the first ILS module started at approximately 4:10 PM on September 24, 2007. Initial module testing continued for 420 hours. The test average $\mathrm{H}_{2}$ production rate was approximately $1.3 \mathrm{Nm}^{3} / \mathrm{hr}$ $\left(0.116 \mathrm{~kg} \mathrm{H}_{2} / \mathrm{hr}\right)$, with a peak measured value of over $2 \mathrm{Nm}^{3} / \mathrm{hr}\left(0.179 \mathrm{~kg} \mathrm{H}_{2} / \mathrm{hr}\right)$. Significant module performance degradation was observed over the first 250 hours, after which no further degradation was noted for the remainder of the test. Once all test objectives had been successfully met, the test was terminated in a controlled fashion. Discussion is included concerning several modifications that will be incorporated into the facility components to improve reliability and ease of operation for future long term testing. 


\section{TABLE OF CONTENTS}

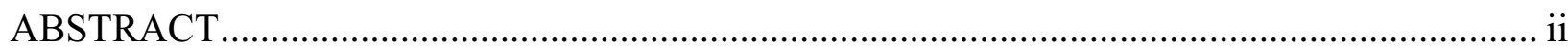

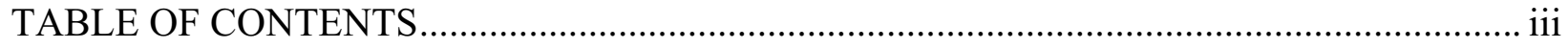

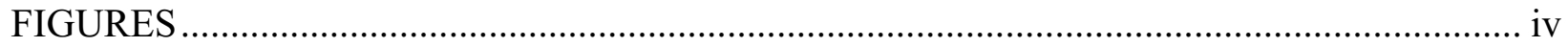

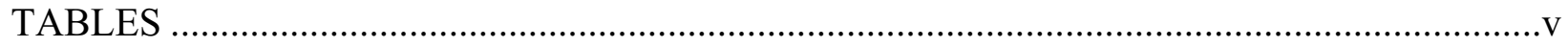

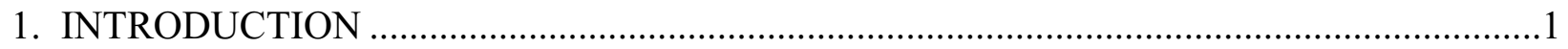

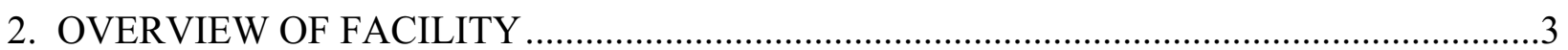

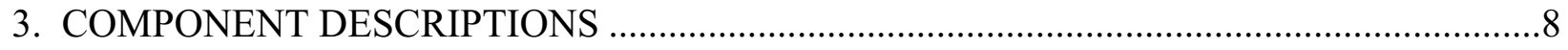

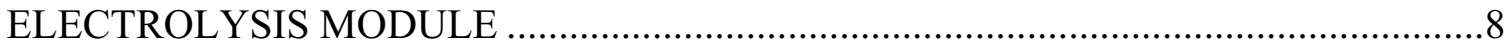

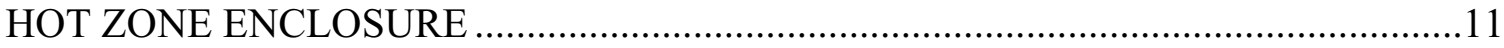

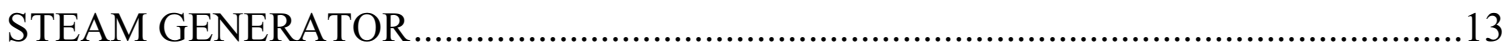

STEAM SUPERHEATER AND AIR HEATER ………….....................................13

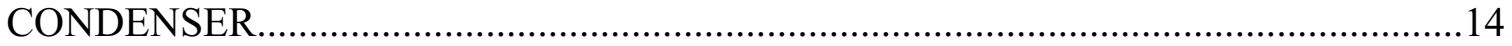

DATA ACQUISITION AND CONTROL SYSTEM ………………………………....14

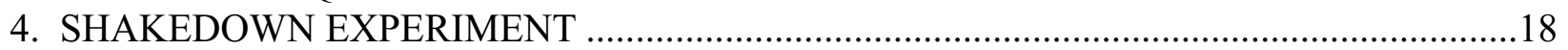

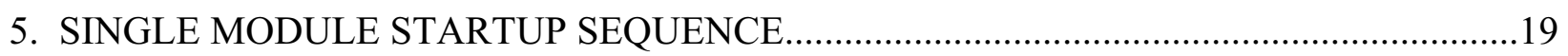

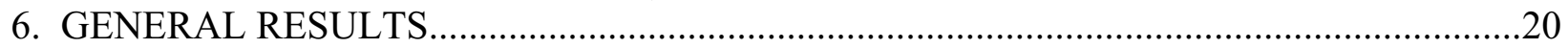

ELECTROLYSIS MODULE - HEATUP AND FIRST 50 HOURS ………………......20

ELECTROLYSIS MODULE - INITIAL SWEEP .......................................................22

ELECTROLYSIS MODULE - LONG DURATION TEST ……...................................23

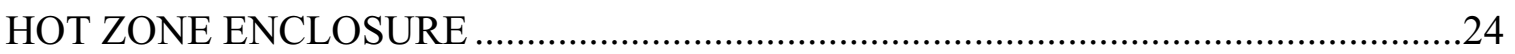

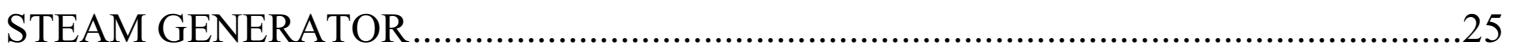

STEAM SUPERHEATER TRANSIENT AND STEADY-STATE BEHAVIOR .............27

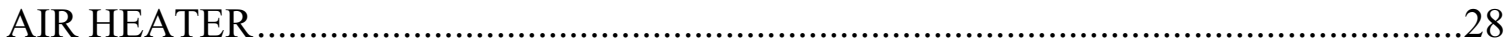

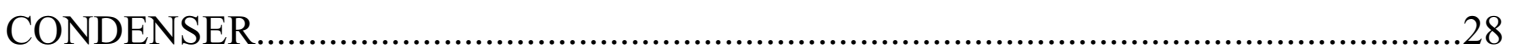

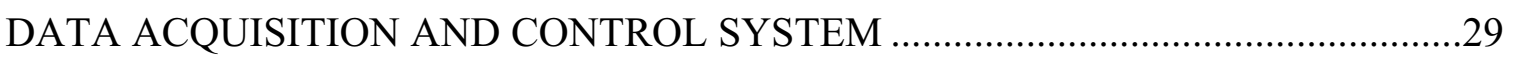

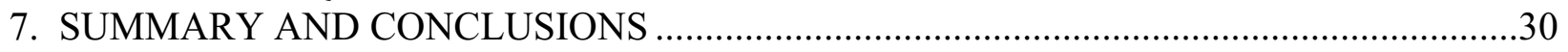

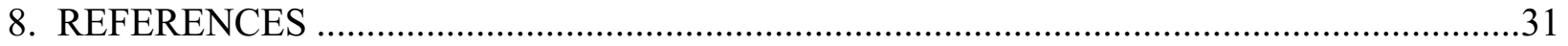




\section{FIGURES}

Figure 1. Typical high temperature electrolysis button cell $(\sim 1.5 \mathrm{~W})(\mathrm{a})$, planar 10 -cell stack $(\sim 500 \mathrm{~W})(\mathrm{b})$, and the two halves $(4 \times 60$ cells $)$ of a single ILS module $(\sim 5 \mathrm{~kW})(\mathrm{c}) \ldots \ldots .2$

Figure 2. ILS single module piping and instrumentation schematic.......................................

Figure 3. Right side view of INL ILS facility, with major components labeled........................6

Figure 4. Left side view of INL ILS facility, with major components labeled.........................7

Figure 5. Front view of INL ILS facility, with major components labeled. ..............................7

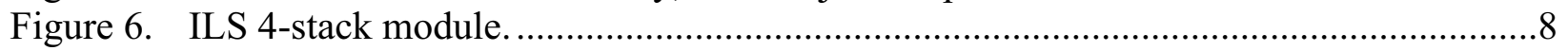

Figure 7. Diagram of solid-oxide stack components.....................................................

Figure 8. One-half of ILS module showing electrical interconnections. ................................9

Figure 9. Two ILS half modules back-to-back, showing electrical interconnections and air

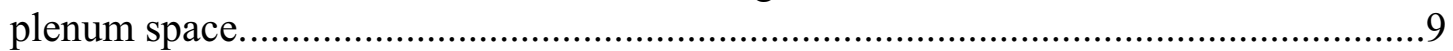

Figure 10. ILS module with spring-loaded compression bars. ..............................................10

Figure 11. Final installation of ILS module with instrumentation and power attachments..........10

Figure 12. HTE ILS hot zone with three modules installed..................................................11

Figure 13. Hot zone enclosure with one module installed. ................................................12

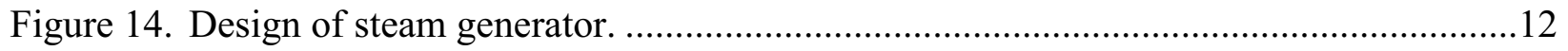

Figure 15. Air heater and steam superheater internal piping. .............................................. 13

Figure 16. Condenser and condensate tank.................................................................... 14

Figure 17. National Instruments SCXI-1001 data acquisition, control, and signal conditioning electronics with SCXI-1600 digital voltmeter and USB interface............................15

Figure 18. Screen display of the INL-developed data acquisition and control program. This program was written using the National Instruments LabView software...................15

Figure 19. ILS initial module heatup temperature trace.....................................................21

Figure 20. ILS module voltage sweep / polarization curve data.............................................22

Figure 21. ILS module voltage sweep $\mathrm{H}_{2}$ production rates and dew points. ............................22

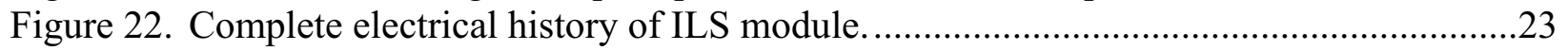

Figure 23. Post test photograph of the ILS initial module. ................................................24

Figure 24. Hot zone steady state power, interior, and exterior surface temperature....................24

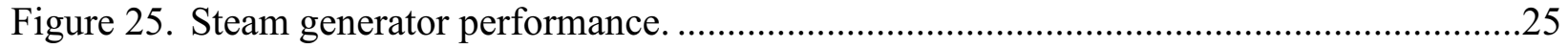

Figure 26. Steam generator internal temperatures..................................................................26

Figure 27. Steam superheater performance........................................................................27

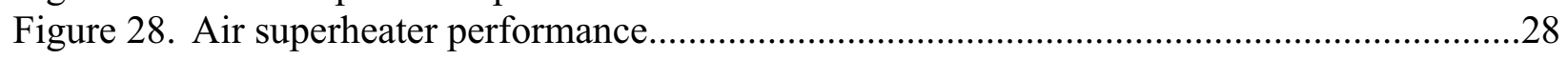

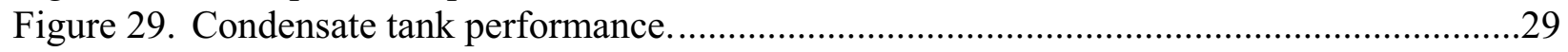




\section{TABLES}

Table 1. Test objectives for various scales of high-temperature electrolysis facilities...............1

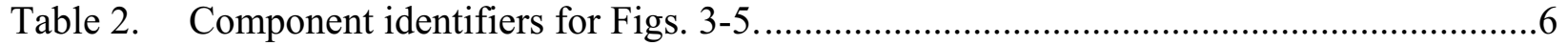

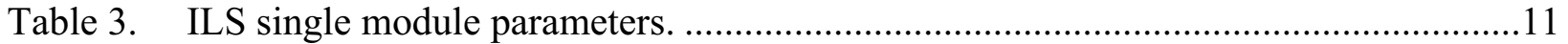

Table 4. Single module ILS data acquisition and control channel list.............................. 16-17

Table 5. Operating conditions for ILS module voltage sweep. ........................................21

Table 6. Long duration operating conditions for ILS module. ..............................................23 


\section{INTRODUCTION}

The Research and Development Plan for the Nuclear Hydrogen Initiative (NHI) specifies a progression of research and development activities, including experimental activities, proceeding from small-scale bench testing to large-scale demonstration. For high-temperature electrolysis, the experimental research objectives at the Idaho National Laboratory (INL) have been organized with increasing scale as follows:

- Button cell fabrication and testing $\left(\sim 1 \mathrm{~W}\right.$ (or $\left.\sim 30 \mathrm{mg} \mathrm{H}_{2} / \mathrm{hr}\right)$ ) -- cell material development and performance characterization

- Stack development and testing (200 W - $15 \mathrm{~kW}$ (or $0.006-0.450 \mathrm{~kg} \mathrm{H} / \mathrm{hr}$ )) -- stack design (electrode and electrolyte materials, interconnect and flow field materials and fabrication, inter-cell electrical contact, cell and manifold sealing issues, and cell durability)

- Integral issues (15 kW (or $0.450 \mathrm{~kg} \mathrm{H} / \mathrm{hr}$ )) -- feed-stock heating, high-temperature gas handling, multiple-stack thermal management, and heat recuperation

- Facility (200/500 kW and $5 \mathrm{MW}$ (or $6 / 15 \mathrm{~kg} \mathrm{H}_{2} / \mathrm{hr}$ and $150 \mathrm{~kg} \mathrm{H}_{2} / \mathrm{hr}$ )) -- facility and production issues including energy management, utility requirements, high pressure operation, and product purification.

Test objectives for the various scales of operation and testing are also summarized in Table 1.

Table 1. Test objectives for various scales of high-temperature electrolysis facilities.

\begin{tabular}{|l|c|c|c|c|c|}
\hline \multirow{2}{*}{} & \multirow{2}{*}{ Button } & \multicolumn{2}{|c|}{ Stack } & \multicolumn{2}{c|}{ Facility } \\
\cline { 3 - 6 } & $(1.5 \mathrm{~W})$ & $\begin{array}{c}\text { Bench } \\
(500 \mathrm{~W})\end{array}$ & $\begin{array}{c}\text { Integrated } \\
\text { Lab }(15 \mathrm{~kW})\end{array}$ & $\begin{array}{c}\text { Pilot } \\
(200 \mathrm{~kW})\end{array}$ & $\begin{array}{c}\text { Engineering } \\
\text { Demonstration } \\
(5 \mathrm{MW})\end{array}$ \\
\hline Electrode / Electrolyte Materials & $\mathrm{x}$ & & & & \\
\hline Electrode/Electrolyte performance & $\mathrm{x}$ & $\mathrm{x}$ & & & \\
\hline Basic cell design & $\mathrm{x}$ & $\mathrm{x}$ & & & \\
\hline Stack design & & $\mathrm{x}$ & & & \\
\hline Stack sealing & & $\mathrm{x}$ & $\mathrm{x}$ & & \\
\hline Stack performance & & $\mathrm{x}$ & $\mathrm{x}$ & & \\
\hline Manifolding & & $\mathrm{x}$ & $\mathrm{x}$ & $\mathrm{x}$ & \\
\hline Electrical configuration & & & $\mathrm{x}$ & $\mathrm{x}$ & \\
\hline Instrumentation development & $\mathrm{x}$ & $\mathrm{x}$ & $\mathrm{x}$ & $\mathrm{x}$ & \\
\hline Heating of feedstock & & & $\mathrm{x}$ & $\mathrm{x}$ & $\mathrm{x}$ \\
\hline Product gas heat recuperation & & & $\mathrm{x}$ & $\mathrm{x}$ & $\mathrm{x}$ \\
\hline Hydrogen recycle & & & $\mathrm{x}$ & $\mathrm{x}$ & $\mathrm{x}$ \\
\hline High-temperature oxygen handling & & & $\mathrm{x}$ & $\mathrm{x}$ & $\mathrm{x}$ \\
\hline Stack lifetime & & & $\mathrm{x}$ & $\mathrm{x}$ & $\mathrm{x}$ \\
\hline Hydrogen purification & & & & $\mathrm{x}$ & $\mathrm{x}$ \\
\hline System startup and control & & & $\mathrm{x}$ & $\mathrm{x}$ & $\mathrm{x}$ \\
\hline System maintenance & & & & $\mathrm{x}$ & $\mathrm{x}$ \\
\hline High-pressure operation & & & & $\mathrm{x}$ & $\mathrm{x}$ \\
\hline Hydrogen storage & & & & & $\mathrm{x}$ \\
\hline $\begin{array}{l}\text { Demonstration of large-scale } \\
\text { hydrogen production }\end{array}$ & & & & $\mathrm{x}$ \\
\hline
\end{tabular}




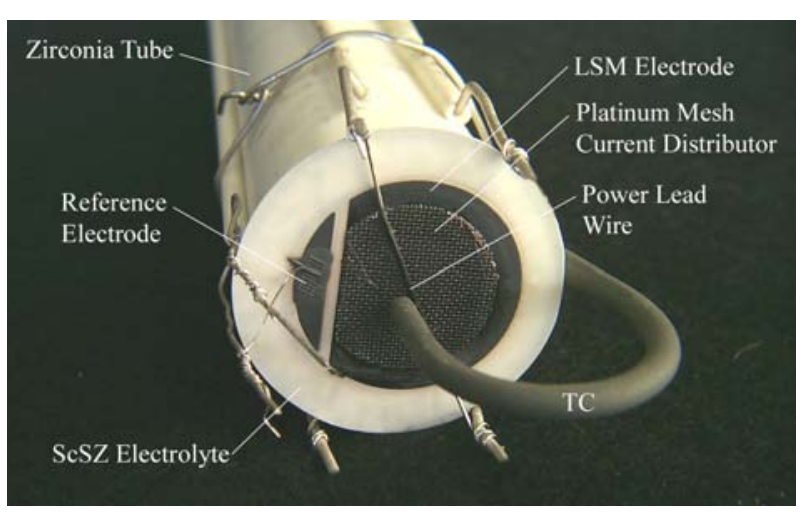

(a)

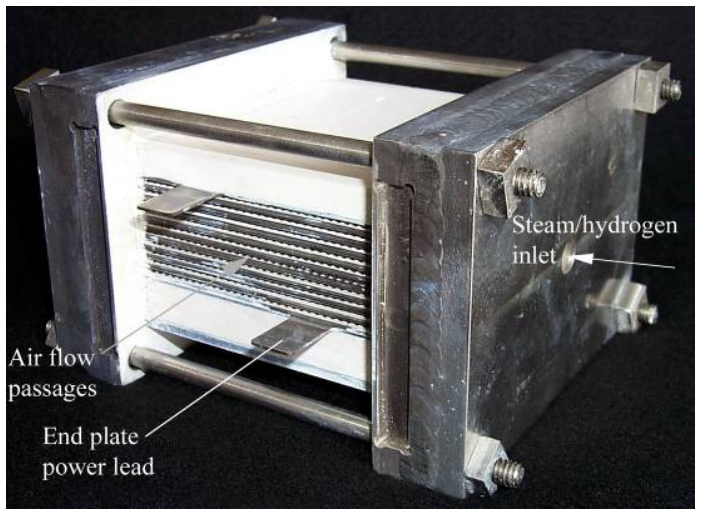

(b)

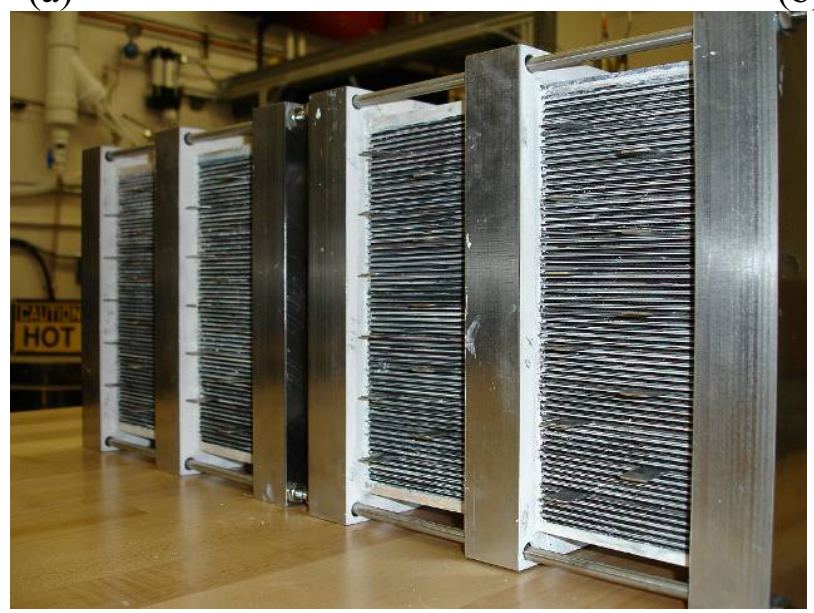

(c)

Figure 1. Typical high temperature electrolysis button cell $(\sim 1.5 \mathrm{~W})(\mathrm{a})$, planar 10-cell stack ( $\left.\sim 500 \mathrm{~W}\left(\sim 0.015 \mathrm{~kg} \mathrm{H}_{2} / \mathrm{hr}\right)\right)$ (b), and the two halves (4x60 cells) of a single ILS module $\left(\sim 5 \mathrm{~kW}\left(\sim 0.150 \mathrm{~kg} \mathrm{H}_{2} / \mathrm{hr}\right)\right)$ (c).

The table includes basic research topics, integral issues, and large-scale demonstration issues. High-temperature electrolysis testing of single button cells and stacks has been in progress at the INL and at the subcontractor Ceramatec Inc. (Salt Lake City, UT) for more than 3 years. The scales of testing accomplished to date at the INL are pictured in Fig. 1. The Integrated Laboratory Scale (ILS) facility has been designed for a nominal hydrogen production rate of 14.1 $\mathrm{kW}$ based on lower heating value (LHV, equal to $120 \mathrm{MJ} / \mathrm{kg}$ for hydrogen) [1], or 4735 Normal $\left(273^{\circ} \mathrm{K}, 1 \mathrm{~atm}\right) \mathrm{L} / \mathrm{hr},(0.423 \mathrm{~kg} \mathrm{H} / \mathrm{hr})$. In this report, we use "normal" and "standard" interchangeably. The initial ILS single module implementation was designed for $\sim 5 \mathrm{~kW}$ hydrogen production.

Per agreement with DOE, the ILS was to be constructed, shakedown tested, and experimental operations of a four-stack (4x60 cells) initial module begun in FY07. Specifically, per the Guidance Letter of August 15, 2006, the initial experimental operations for the ILS experiment will contain a single module of four 60-cell stacks. Later operations in FY-08 will include three modules of the same configuration. Whenever possible, the INL researchers have ordered and installed three sets of supporting equipment. However, the need for access to the first set of steam generator, superheater, condenser, and first module instrumentation during the initial ILS 
operations suggested that the second and third sets of such equipment not be installed until after the first module had been tested.

The ILS began experimental operations in Bay 9 of the Bonneville County Technology Center, Idaho Falls, on August 22, 2007, in fulfillment of a DOE Level 2 milestone. Initial operation included the following.

- The hot zone was heated and maintained at the cell operating temperature $\left(>800^{\circ} \mathrm{C}\right)$.

- The steam generator / superheater combination produced steam at $>800^{\circ} \mathrm{C}$. The air heater produced hot air at $>800^{\circ} \mathrm{C}$.

- A $90 \%$ (volume) steam, $10 \%$ (volume) $\mathrm{H}_{2}$ mixture at $>800^{\circ} \mathrm{C}$ flowed, at 60 normal liters/min, and heated air at 23 normal liters per minute, into the hot zone and out through the coolers and bubblers. The hot air flowed into the interior of the hot zone. The steam flow rate corresponds to a water flow rate of $40 \mathrm{gm} / \mathrm{min}$.

This initial operations test was performed without an electrolysis module installed. Following the shakedown test, a four-stack initial HTE module was installed. Heatup of the first ILS electrolysis module commenced at 4:10 PM on September 24, 2007. The ILS first began producing hydrogen at 8:32 AM on September 25, 2007. The primary objective for this test was to ensure proper design, scaling, fabrication, and operation of all ILS components prior to committing the funding and man-hours necessary for installation and operation of three modules. It was also of interest to quantify large stack performance. Finally, the test was the largest hightemperature steam electrolysis demonstration to date.

This report documents initial operation of the ILS with one four-stack module. A description of the facility with details of the major components is presented. Overall experimental results and documentation of the performance of major components is discussed. Possible improvements in system and component design are also addressed.

This report provides documentation of experimental research activities performed at the Idaho National Laboratory (INL) and at Ceramatec, Inc. during FY07 under the DOE Nuclear Hydrogen Initiative, High Temperature Electrolysis (HTE) Program.

\section{OVERVIEW OF FACILITY}

The piping and instrumentation schematic for the ILS single-module experiment with no heat recuperation or hydrogen recycle is shown in Fig. 2. The electrolysis module requires a support system supplying electrical power for electrolysis, a feedstock gas mixture of hydrogen and steam, a sweep gas, and appropriate exhaust handling. In particular, this system must include means for controlled steam generation, mixing hydrogen with the steam, feedstock and product dewpoint measurements, heating the feedstock and sweep gas to the appropriate electrolysis temperature (via a superheater), cooling the electrolysis product stream, condensing any residual steam out of the product stream, and venting the hydrogen product. The final ILS support system will consist of three parallel systems that supply feedstock, sweep gas streams, and electrical power basically independent of each other to each of three modules. All three modules will be located within a single hot zone. The facility is designed to accommodate later incorporation of heat recuperation and hydrogen recycle capabilities. To aid in interpretation of 


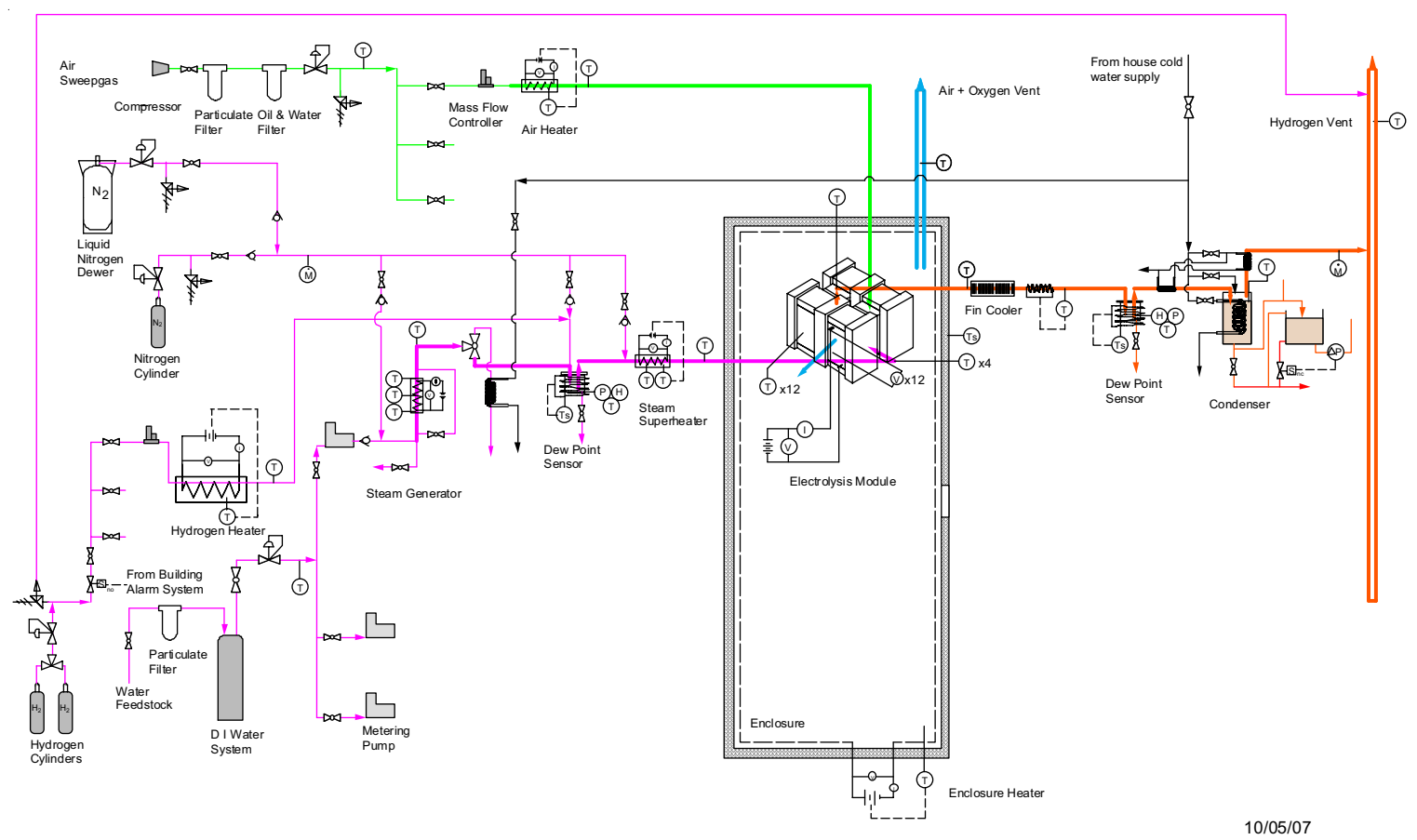

Figure 2. ILS single module piping and instrumentation schematic.

Fig. 2, the hydrogen / steam feedstock is represented by the color magenta, the product stream by orange, the inlet sweep gas by green, and the outlet sweep gas by blue.

Liquid water feedstock is fed at a controlled rate into the system by means of a positivedisplacement metering pump. The water is then vaporized and slightly superheated in an inline electrically-powered steam generator, the design of which is discussed in greater detail below. The steam mass flow rate is verified by monitoring the rate of electrical energy supplied to the steam generator from the DC power supply. The slightly superheated steam exiting the steam generator is mixed with hydrogen, which is required on the inlet side of the stack in order to maintain reducing conditions at the steam/hydrogen electrode. In the initial ILS configuration (prior to the implementation of hydrogen recycle), the inlet hydrogen will be supplied from a compressed gas bottle. The hydrogen flow rate is controlled by a mass-flow controller and the data acquisition / control system (DACS). The inlet hydrogen must be heated to the steam generator outlet temperature in order to prevent cooling of the steam and possible steam condensation. This is accomplished by temperature-based feedback control of the hydrogen preheater powered by a DC power supply in conjunction with the DACS. Downstream of the mixing point, the temperature, pressure, and dewpoint of the steam/hydrogen gas mixture are measured. The absolute pressure is directly measured at the dewpoint measurement station in order to allow for accurate determination of the steam mole fraction. Precise measurement of the dewpoint and pressure allows for independent determination of the inlet gas composition.

A high-temperature electrically powered inline superheater then boosts the feedstock stream to the final electrolyzer operating temperature, $800^{\circ}-830^{\circ} \mathrm{C}$. The design of this custom heater is discussed later. 
The primary material of construction for the low-temperature tubing and components upstream of the superheater is 316 stainless steel. At high temperatures such as $800^{\circ} \mathrm{C}$, Inconel 600 tubing is used within the superheater and air heater.

The electrolysis module is mounted in the hot zone enclosure where it is maintained at the desired operating temperature using radiant heaters installed in the sides and top of the removable lid. As explained in references $[2,3]$, when the electrolysis process is operated below the thermal neutral voltage $\left(\mathrm{V}_{\mathrm{tn}}=1.287 \mathrm{~V} /\right.$ cell for $800^{\circ} \mathrm{C}$ operating temperature $)$, heat must be added to overcome the endothermic reaction heat requirement. At thermal neutral conditions, the module operation is adiabatic and isothermal. If, however, the module is operated above the thermal neutral voltage, excess ohmic heating of the stack must be removed from the system.

The gas mixture exiting the electrolyzer will be significantly enriched in hydrogen, typically to at least $50 \%$ hydrogen mole fraction, with the remainder being residual steam. The product stream is first cooled via a natural-convection air-cooled heat exchanger. The product stream temperature exiting this cooler is controlled such that no condensation can occur. Then the product gas mixture enters the outlet dewpoint measurement station. As discussed previously, the measurement of both inlet and outlet dewpoint temperatures allows for direct determination of the steam consumption rate, and the corresponding hydrogen production rate. This rate can be compared to the electrochemical hydrogen production rate determined from the stack electrical current. The outlet hydrogen/steam flow then enters a condenser where the vast majority of the residual steam is removed. The rate of water condensation is monitored via tank level, providing an additional independent measure of steam consumption. At this point, the product stream will be ambient-temperature, saturated hydrogen gas, with about 3.7\% residual water vapor. The flow rate of this product gas is measured with a low-pressure-drop mass flow transducer. Comparison of the condensate and hydrogen product mass flow rates with the electrolyzer inlet mass flow rates helps quantify any stack leakage that may occur. The hydrogen product is then vented from the building.

Air is used as a sweep gas to remove excess oxygen from the ILS system. Filtered compressed air flows through a mass-flow controller and into an electrically-powered heater to preheat the inlet air to the stack operating temperature. Downstream of the electrolyzer, the hot oxygenenriched air stream is then vented from the building to the environment.

Nitrogen gas can be injected directly into the steam superheater. This feature is used during startup until the superheater outlet temperature reaches about $400^{\circ} \mathrm{C}$ to preclude any liquid entering the HTE module. During some scenarios, nitrogen gas may continue to be injected during steady state operation. For instance, if a module is found to be particularly leaky, nitrogen can be used to increase the average molecular weight of the gas mixture and hence reduce hydrogen diffusion rates. The nitrogen can be supplied from either a compressed gas cylinder or from a liquid nitrogen Dewar.

Detailed process flow sheets were developed for the ILS design using the commercial systemanalysis code UniSim. These flow sheets include all of the components that would be present in the actual ILS facility such as pumps, blowers, heat exchangers, and the electrolyzer. Since the electrolyzer is not a standard UniSim component, a custom one-dimensional electrolyzer model was developed for incorporation into the overall process flow sheet. This electrolyzer model 
allows for the determination of the $\mathrm{H}_{2}$ production rate, average Nernst potential, cell operating voltage, gas outlet temperatures, and electrolyzer efficiency for any specified inlet steam, hydrogen, and sweep-gas flow rates, current density, cell active area, and external heat loss or gain. The model includes a temperature-dependent area-specific resistance (ASR) that accounts for the significant increase in electrolyte ionic conductivity that occurs with increasing temperature. Details concerning this one-dimensional model and its implementation in UniSim have been reported in [2, 3].

All of the system components and hardware were mounted on a skid that is $16 \mathrm{ft}$. long by 10 $\mathrm{ft}$ wide. Photographs of the skid with the components identified are presented in Figs. 35. The components are listed in Table 2 by identification number. A custom LabView (National Instruments) program was developed for ILS data acquisition and instrument control using SCXI data acquisition hardware.
Table 2. Component identifiers for Figs. 3-5.

\begin{tabular}{|c|c|}
\hline ID & Component \\
\hline 1 & Electrolysis stacks / module \\
2 & Hot zone enclosure lid \\
3 & Power supply and instrument racks \\
4 & Electrical distribution cabinets \\
5 & Data acquisition and control monitors \\
6 & Deionized water system \\
7 & Water supply metering pump \\
8 & Steam generator \\
9 & $\mathrm{H}_{2}$ preheater \\
10 & Steam and $\mathrm{H}_{2}$ superheater \\
11 & Air compressor \\
12 & Air heater \\
13 & Product finned cooler \\
14 & Steam condenser \\
15 & Condensate tank \\
16 & $\mathrm{H}_{2}$ mass flow meter \\
17 & $\mathrm{H}_{2}$ vent \\
18 & Air and $\mathrm{O}_{2}$ vent \\
19 & Dew point sensor \\
\hline
\end{tabular}

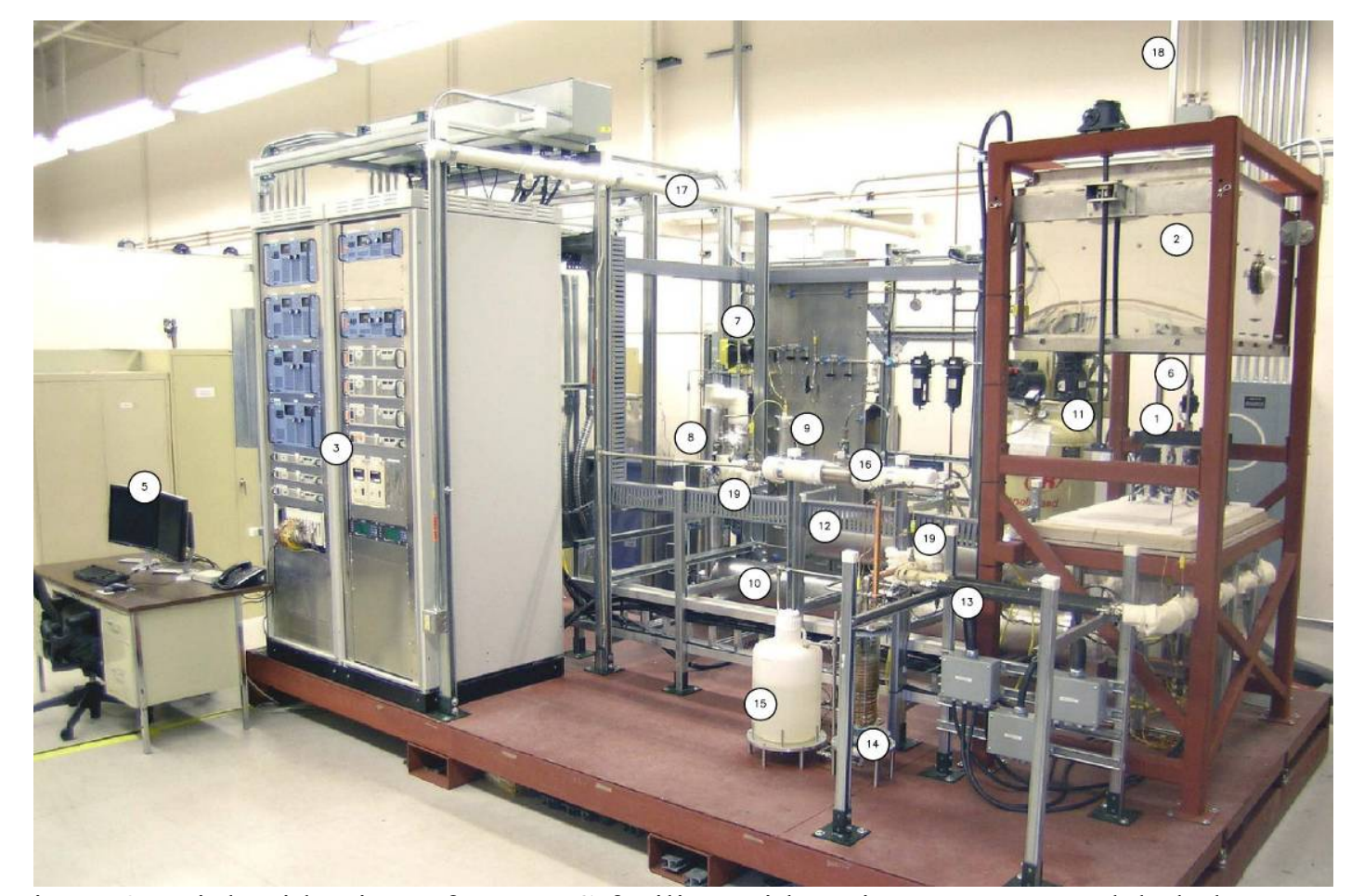

Figure 3. Right side view of INL ILS facility, with major components labeled. 


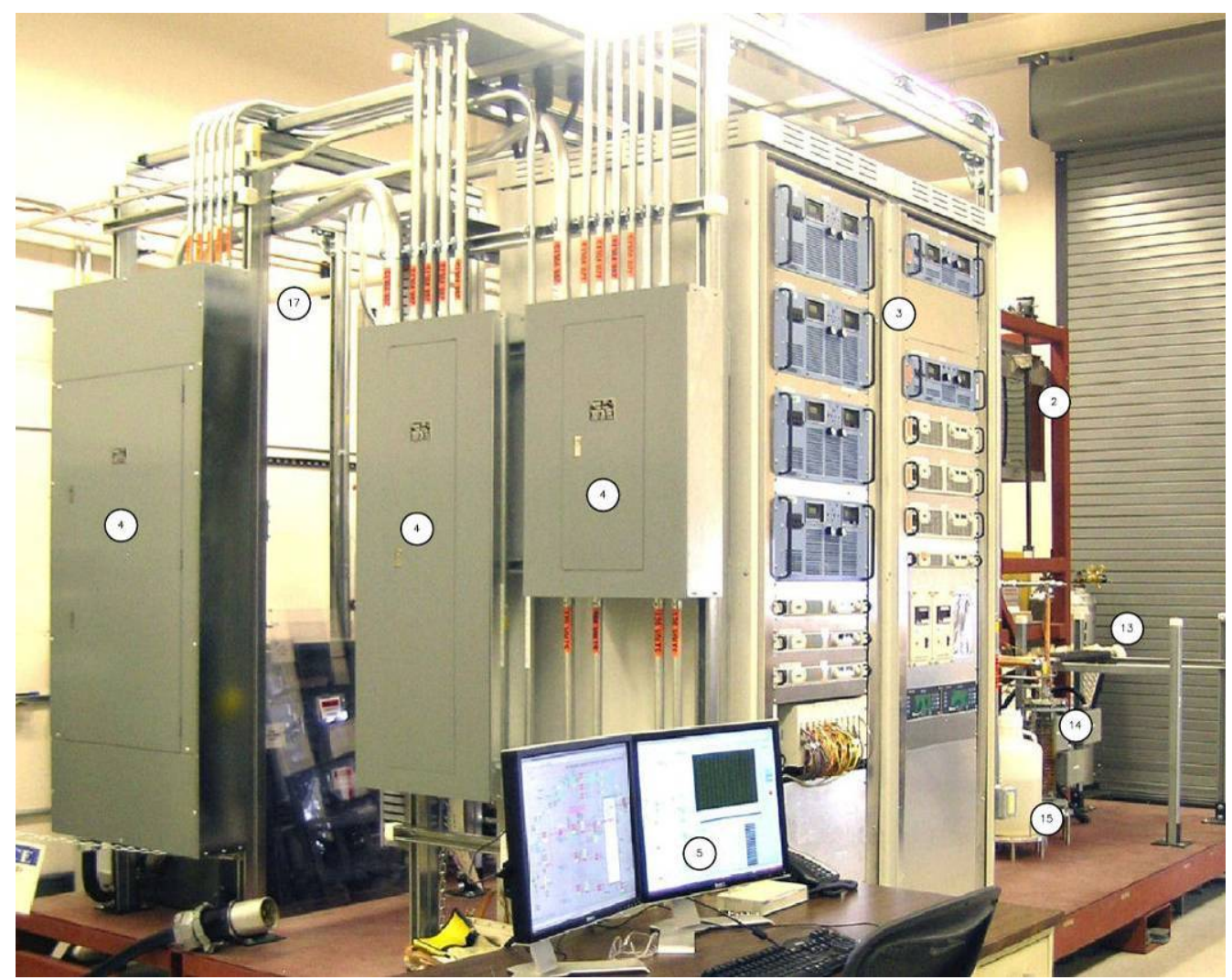

Figure 4. Left side view of INL ILS facility, with major components labeled.

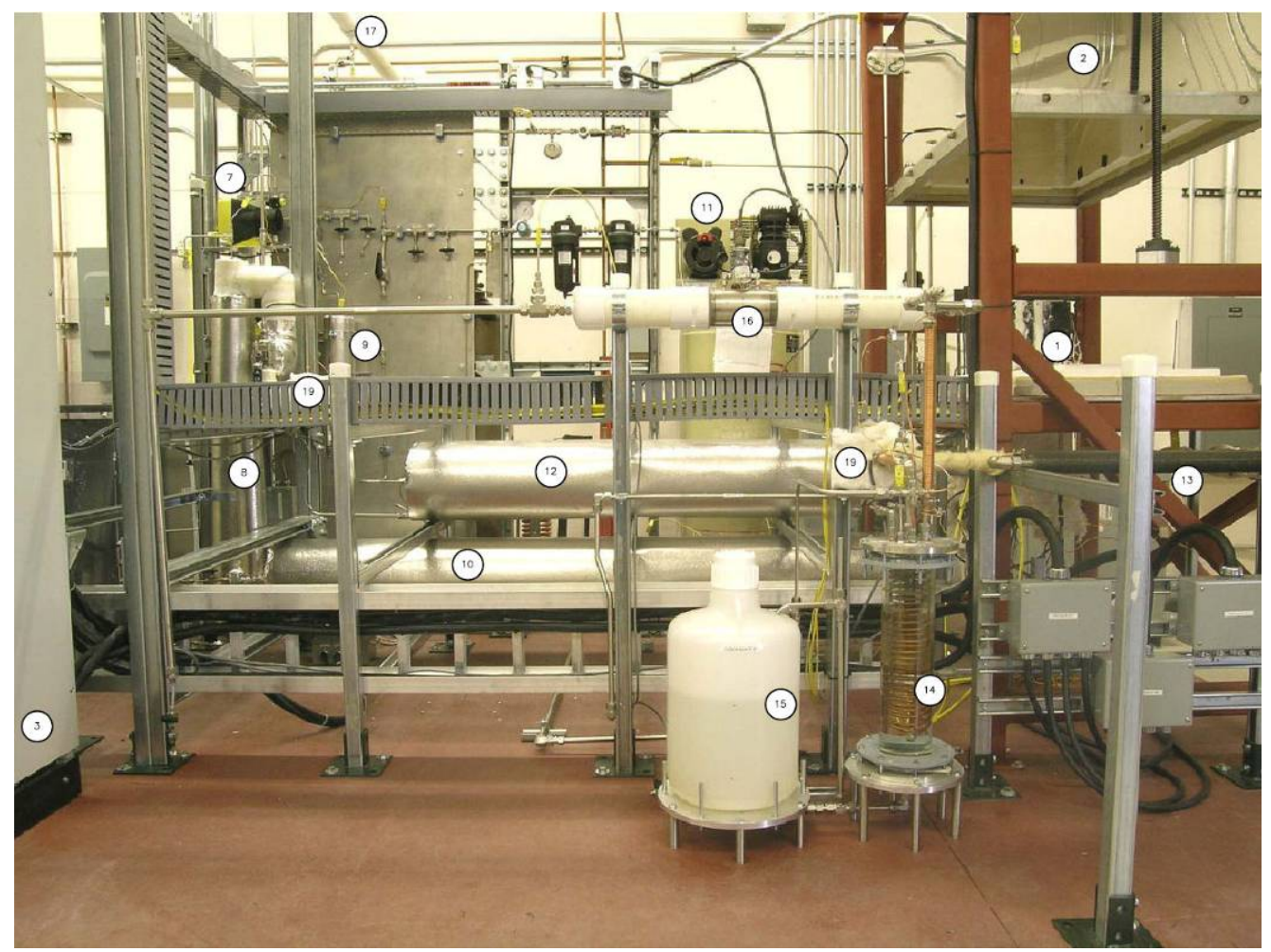

Figure 5. Front view of INL ILS facility, with major components labeled. 


\section{COMPONENT DESCRIPTIONS}

\section{ELECTROLYSIS MODULE}

Stacks used for testing by the INL are fabricated by Ceramatec, Inc., of Salt Lake City, UT. They have a active area of $64 \mathrm{~cm}^{2}$ per cell, providing a total active area of 3840 $\mathrm{cm}^{2}$ in a sixty-cell stack. They are designed to operate in cross flow, with the steam / hydrogen gas mixture entering the inlet manifolds on the right and left sides in Fig. 6, and exiting through the outlet manifold visible in Fig. 6. Airflow enters at the rear through an air inlet manifold (Fig. 6) and exits through the front and back open faces directly into the hot zone enclosure.

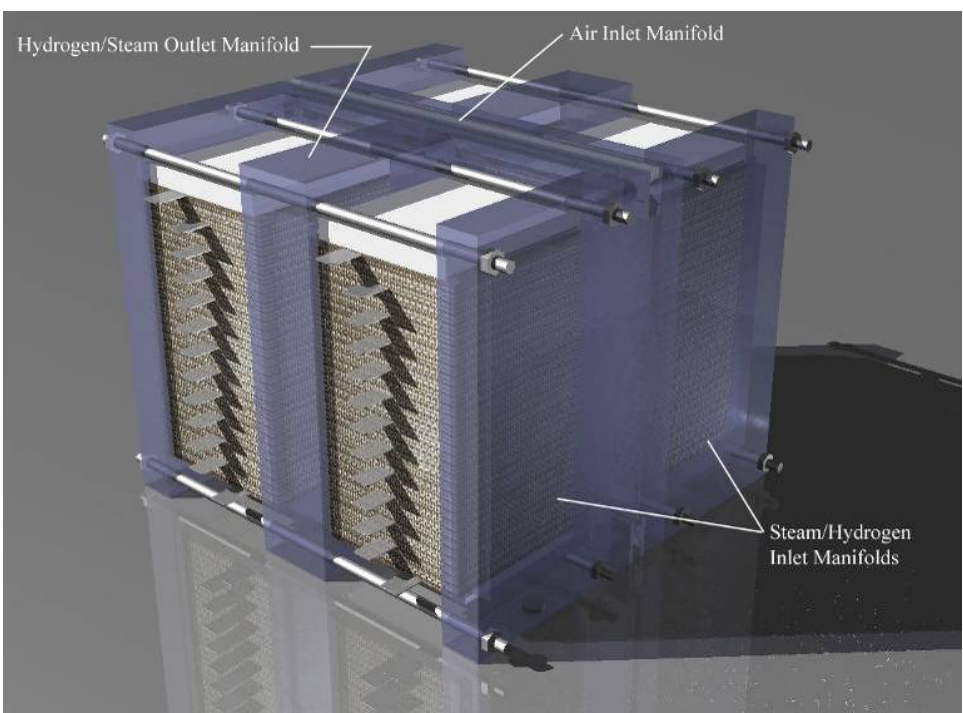

Figure 6. ILS 4-stack module.

The internal components of the stack are shown in Fig. 7 and are comprised as follows. The interconnect plate is fabricated primarily from ferritic stainless steel. It includes an impermeable separator plate $(\sim 0.46 \mathrm{~mm}$ thick) with edge rails and two corrugated flow fields, one on the sweep-gas side and one on the steam / hydrogen side. The height of the flow fields is $1.0 \mathrm{~mm}$. Each flow field includes 32 perforated flow channels across its width to provide uniform gasflow distribution. The steam / hydrogen flow fields are fabricated from nickel foil. The airsweep flow fields are made from ferritic stainless steel. The interconnect plates and flow fields also serve as electrical conductors and current distributors. To improve performance, the sweep-side separator plates and flow fields are surface-treated to form a rare-earth stable conductive oxide scale. A perovskite rare-earth coating is also applied to the separator plate oxide scale by either screen printing or plasma spraying. On the steam / hydrogen side of the

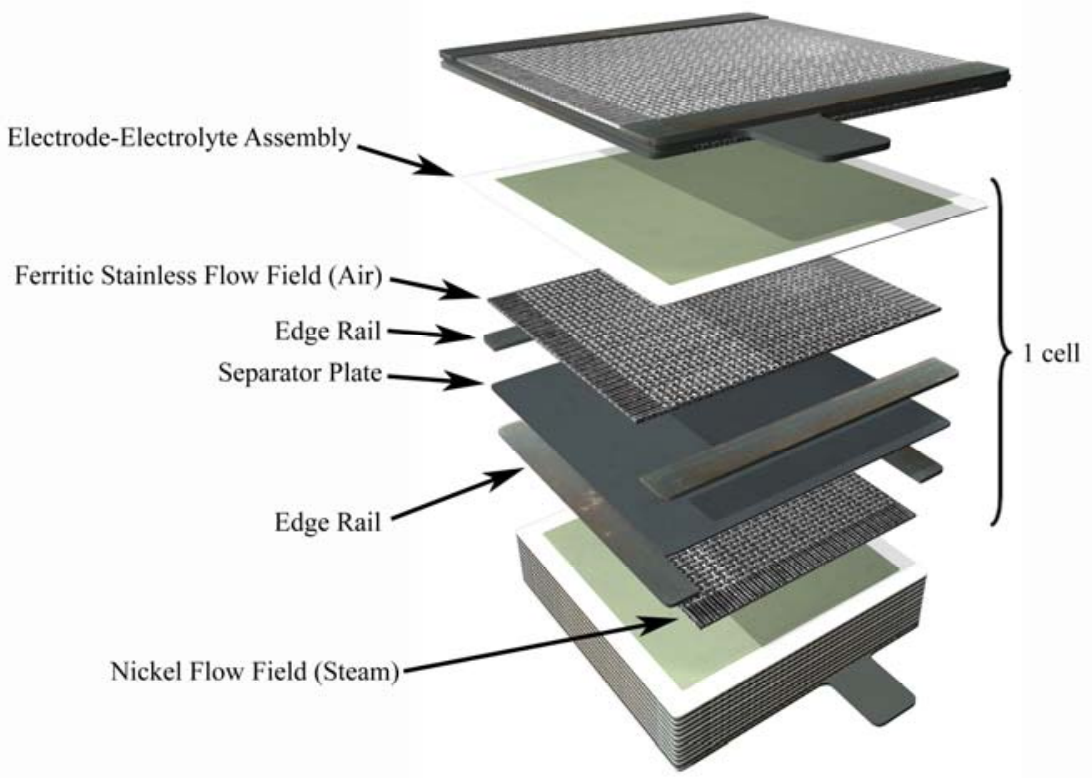

Figure 7. Diagram of solid-oxide stack components. 
separator plate, a thin $(\sim 10 \mu \mathrm{m})$ nickel metal coating is applied.

The electrolyte is scandia-stabilized zirconia, $\sim 140 \mu \mathrm{m}$ thick. The sweepside electrode (anode in the electrolysis mode) is a strontiumdoped manganite. The electrode is graded, with an inner layer of manganite/zirconia $\quad(\sim 13 \mu \mathrm{m})$ immediately adjacent to the electrolyte, a middle layer of manganite $(\sim 18 \mu \mathrm{m})$, and an outer bond layer of cobaltite. The steam / hydrogen electrode (cathode in the electrolysis mode) is also graded, with a nickel cermet layer $(\sim 13 \mu \mathrm{m})$ immediately adjacent to the

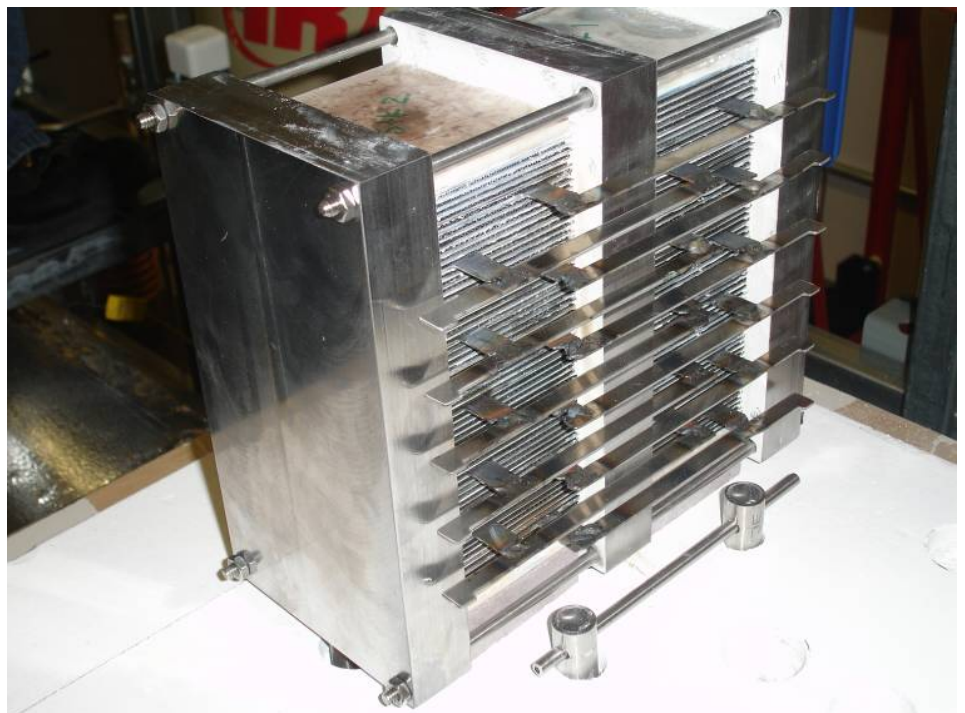

Figure 8. One-half of ILS module showing electrical interconnections.

electrolyte and a pure nickel outer layer $(\sim 10 \mu \mathrm{m})$.

The electrolysis module is composed of four stacks, each consisting of sixty cells (Fig. 6). Two stacks with individual inlet plenums are connected together with a common outlet plenum to form a half-module. To preclude the loss of an entire stack if a single cell fails, the four stacks are electrically interconnected at every fifth cell. This is done by first interconnecting the pair of stacks in each half module, as shown in Fig. 8, and then interconnecting the two half modules when they are in final position (Fig. 9). When the two half-modules are placed back-to-back a common air inlet plenum for all four stacks is formed. Spring loaded bars are placed over the stacks to maintain a compressive load on the stacks during operation (Fig. 10). Power leads to each stack, intermediate voltage taps and interior thermocouples were then attached, and subsequent sealing of gaps completed the installation (Fig. 11).

A summary of the nominal performance characteristics of the ILS for one module is provided in Table 3. In the final ILS configuration, we are planning to use 3 modules, each of which will include 4 stacks of 60 cells each, totaling 720 cells. The nominal performance of the 3-module system can be scaled from Table 3. All three of the ILS modules will be incorporated into a single hot zone for the ILS, as displayed in Fig. 12. The hot zone is an insulated enclosure with embedded electrical-resistance guard heaters. Operating parameters for the single module based on this preliminary design are provided in Table 3.

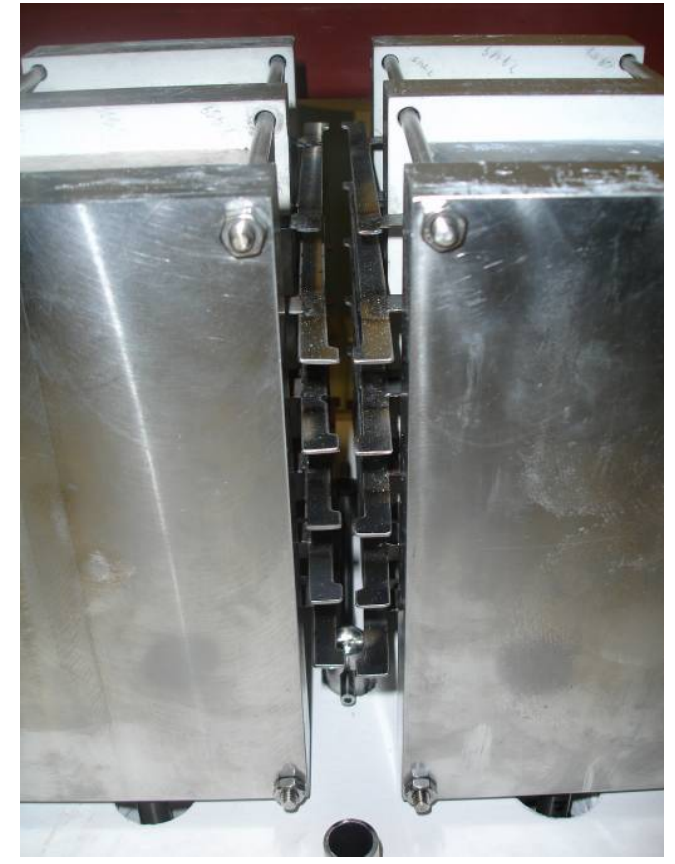

(b)

Figure 9. Two ILS half modules backto-back, showing electrical interconnections and air plenum space. 
The per-cell area-specific resistance (ASR) value of $1.5 \mathrm{Ohm}-\mathrm{cm}^{2}$ in Table 3 represents a conservative value that has already been validated in stack tests. Note that for nominal operating conditions with a modest current density of $0.271 \mathrm{~A} / \mathrm{cm}^{2}$ and the flow rates shown, a hydrogen production rate in excess of $1700 \mathrm{NL} / \mathrm{hr}(0.152 \mathrm{~kg}$ $\mathrm{H}_{2} / \mathrm{hr}$ ), could be expected. Actual test results showed average $\mathrm{H}_{2}$ production rates lower than this, but peak $\mathrm{H}_{2}$ production rates were higher.

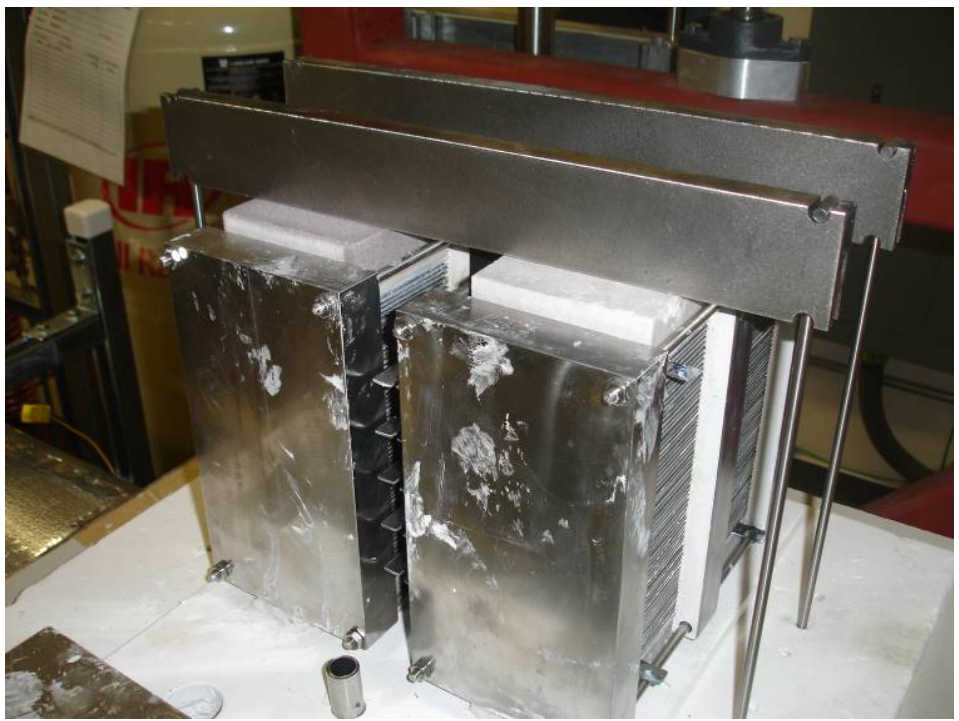

Figure 10. ILS module with spring-loaded compression bars.

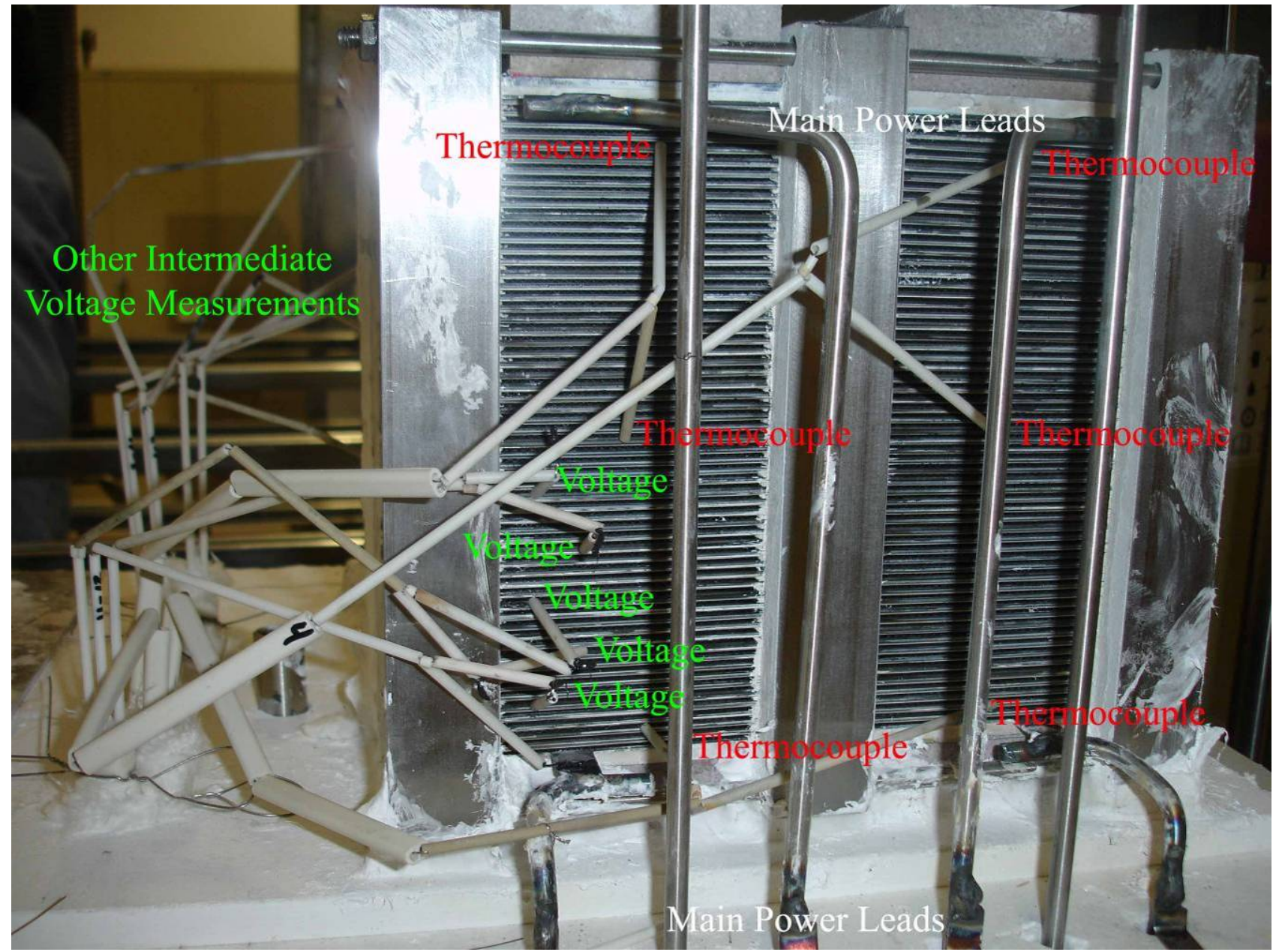

Figure 11. Final installation of ILS module with instrumentation and power attachments. 


\section{HOT ZONE ENCLOSURE}

The ILS hot zone enclosure houses the electrolysis modules and is designed to maintain the modules at the desired operating temperature. The base of the enclosure consists of a stainless steel plate covered with several inches of high-temperature insulation as shown in Fig. 13. The modules rest on top of the insulation. The process streams, power leads, and instrumentation access the module through holes in the bottom plate and

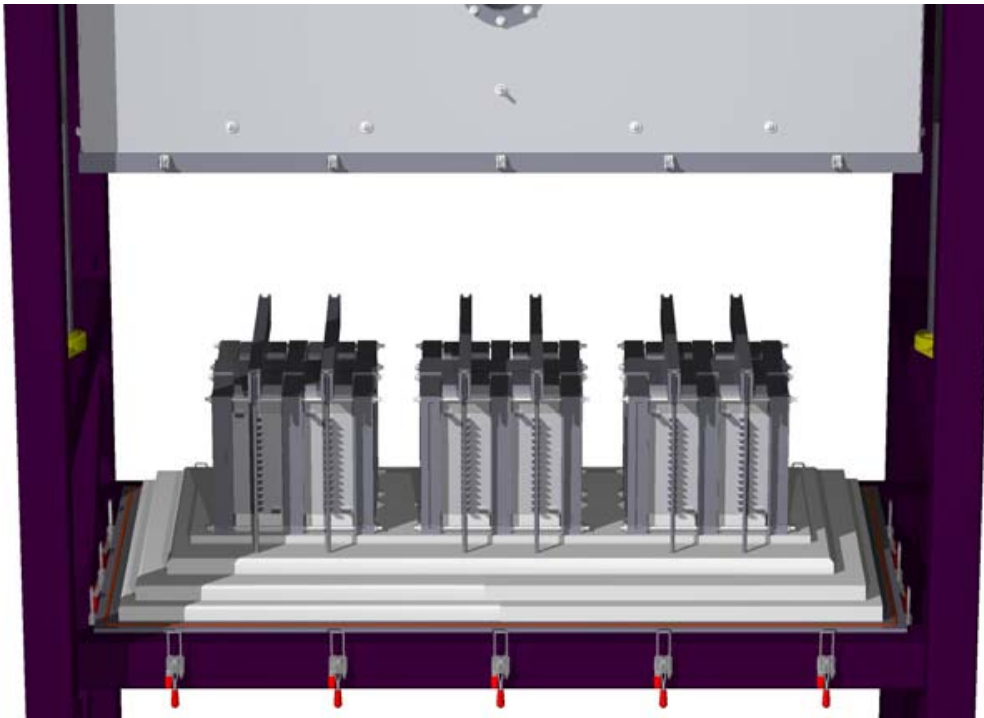

Figure 12. HTE ILS hot zone with three modules installed. insulation. A stainless-steel lid covers the hot zone enclosure and is sealed against the bottom plate with an O-ring. Radiant heater panels, attached to the top and sides of the lid are powered by one of the DC power supplies which are feedback-controlled based on a thermocouple mounted inside the enclosure. The lid is attached to screw-drive rods on each end, driven by an electric motor which allows for convenient raising and lowering of the lid.

Table 3. ILS single module parameters.

\begin{tabular}{|c|c|}
\hline \multicolumn{2}{|c|}{ Independent Design and Operational Parameters } \\
\hline active cell area & $64 \mathrm{~cm}^{2}$ \\
\hline cells per stack & 60 \\
\hline number of stacks & 4 \\
\hline stack operating temperature & $830^{\circ} \mathrm{C}$ \\
\hline steam utilization & $50 \%$ \\
\hline stack operating voltage & $77 \mathrm{~V}$ \\
\hline per-cell ASR & $1.5 \mathrm{Ohm} \mathrm{cm}^{2}$ \\
\hline inlet steam mole fraction & 0.9 \\
\hline inlet hydrogen mole fraction & 0.1 \\
\hline \multicolumn{2}{|c|}{ Calculated Performance Values } \\
\hline per-cell operating voltage & $1.283 \mathrm{~V}$ \\
\hline current density & $0.25 \mathrm{~A} / \mathrm{cm}^{2}$ \\
\hline stack power & $1232 \mathrm{~W}$ \\
\hline total power (electric) & $4.85 \mathrm{~kW}$ \\
\hline inlet hydrogen flow rate & 5.8 NLPM \\
\hline inlet steam flow rate & 53 NLPM \\
\hline inlet liquid water flow rate & $0.7 \mathrm{~g} / \mathrm{s}$ \\
\hline air flow rate & 22.6 NLPM \\
\hline hydrogen production rate & $\begin{array}{l}1578 \mathrm{NL} / \mathrm{hr} \\
\left(0.141 \mathrm{~kg} \mathrm{H}_{2} / \mathrm{hr}\right)\end{array}$ \\
\hline heating value of hydrogen produced & 4.7 kW (LHV) \\
\hline
\end{tabular}




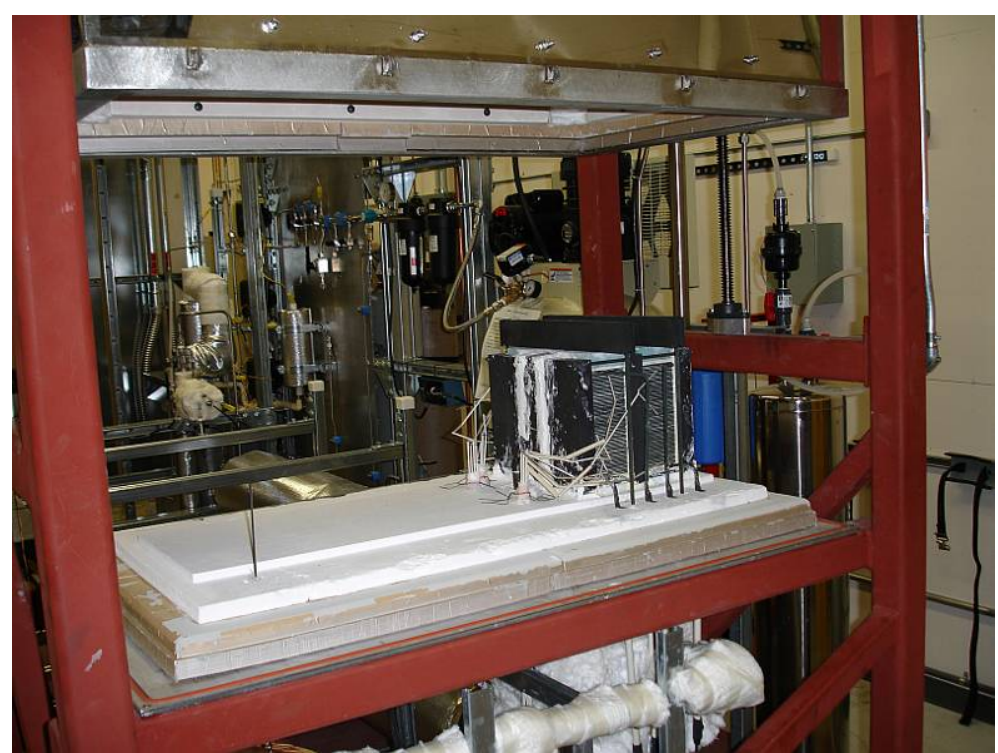

Figure 13. Hot zone enclosure with one module installed.

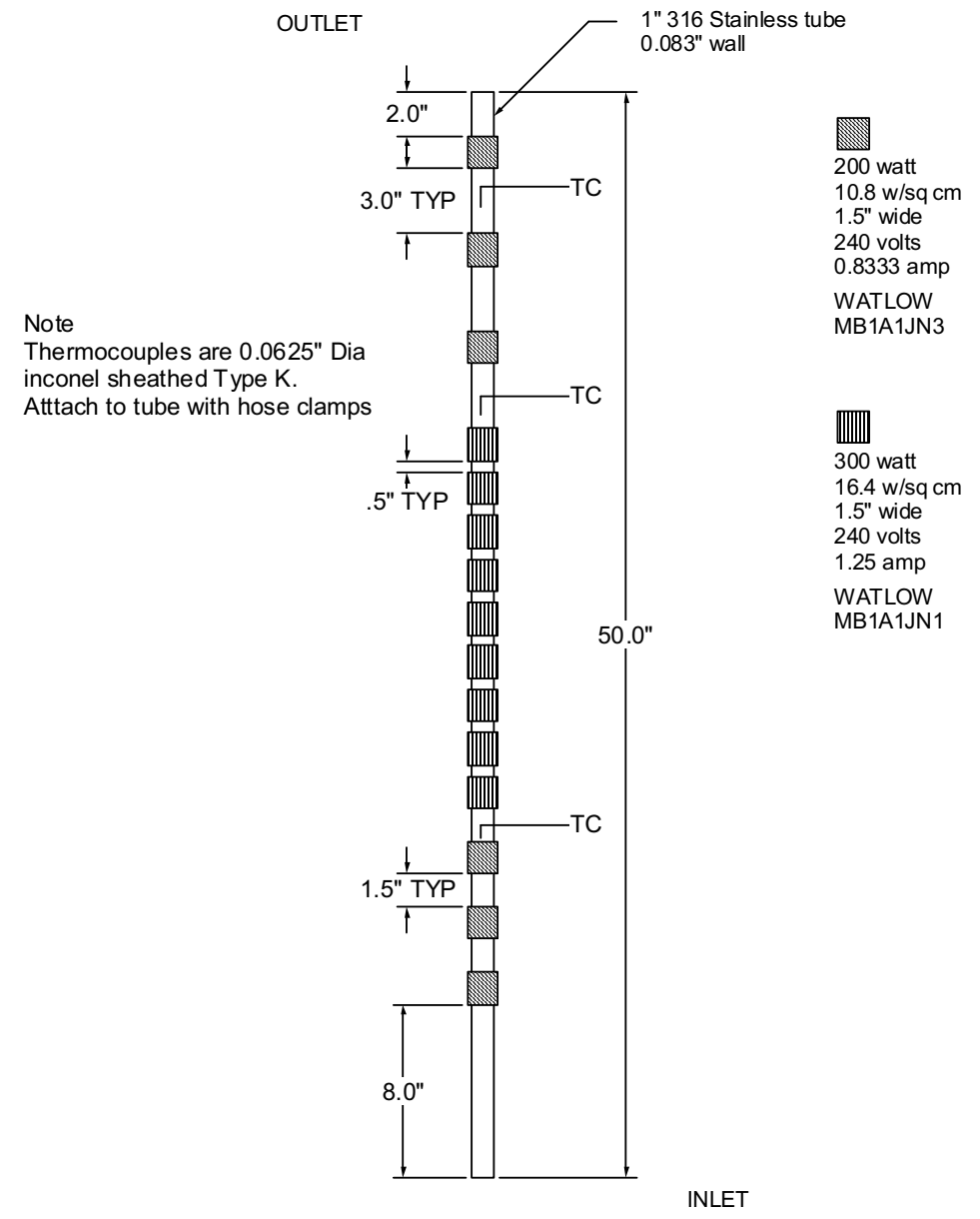

Figure 14. Design of steam generator. 


\section{STEAM GENERATOR}

The steam generator, shown schematically in Fig. 14, heats the inlet water to a superheated temperature of about $150^{\circ} \mathrm{C}$. It was fabricated by attaching a combination of fifteen 200 and 300 watt clamp-on electric heaters to the outside of a 1" diameter stainless steel tube. The heaters are covered with 2" of thermal insulation then topped by an aluminum covering. The heaters are spaced such that a higher heat flux is obtained in the boiling region with lower heat flux in the single-phase regions. The heaters are all wired in parallel so that each operates at the same voltage. The tube interior is filled with a copper foam material which reduces the flow perturbations and increases temperature uniformity in the boiling region. The outlet temperature is controlled by carefully adjusting the input power supplied by a DC power supply to obtain the desired superheat temperature. Input power to the steam generator is not feedback-controlled.

\section{STEAM SUPERHEATER AND AIR HEATER}

These two components have the same design and differ only in length. The heated length for the steam superheater is $6 \mathrm{ft}$. and $4 \mathrm{ft}$ for the air heater. They are used to heat their respective flow streams to approximately $850^{\circ} \mathrm{C}$.

The flow enters the heater through a $3 / 4$ " stainless steel tube and then is divided into four parallel flow paths made from 1/4" schedule- 80 inconel pipe, then recombined into a single flow path as pictured in Fig. 15. The four parallel flow paths create a reduced flow area resulting in an increase in velocity

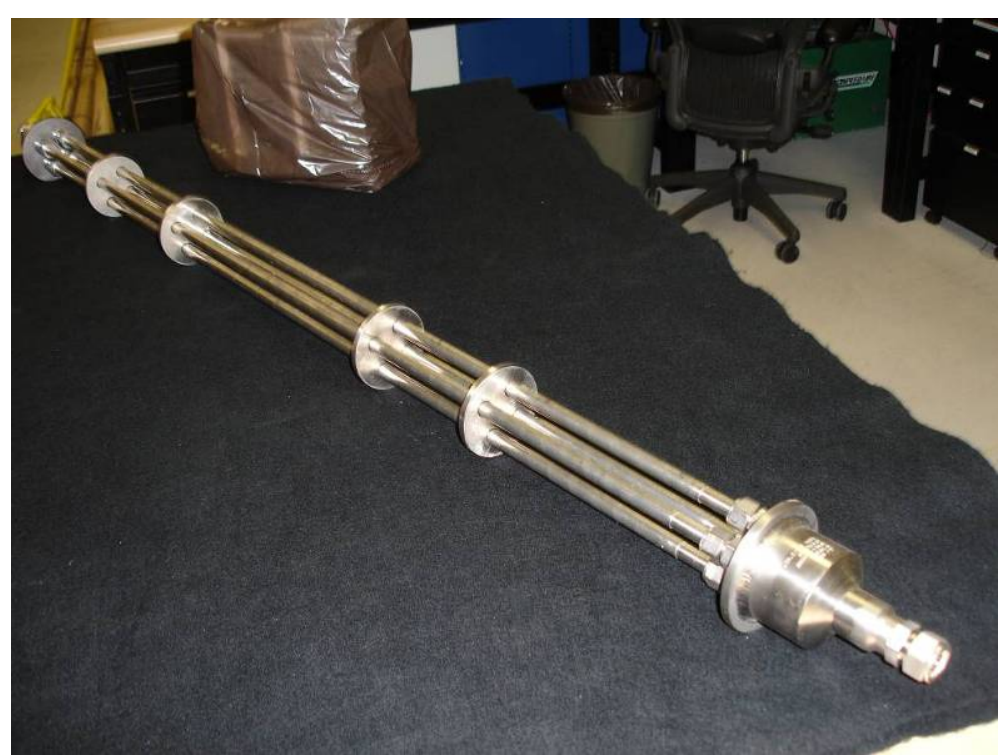

Figure 15. Air heater and steam superheater internal piping. and subsequent heat transfer coefficient. This also increases the ratio of surface area to flow area, reducing the heat flux necessary to obtain the required total power input.

Heat is supplied from Watlow semi-cylindrical ceramic-fiber heaters with embedded coiled elements. Each heater section is capable of providing 1800 watts of power when operated at 240 volts, but they are operated at a much lower voltage for this application. The air heater uses four 24 inch long semi-cylindrical sections while the steam superheater uses six. Power is supplied to the heaters from $3.3 \mathrm{~kW}$ DC power supplies. Heater power is feedback-controlled based on thermocouples located inside the ceramic fiber heaters. Two inch thick high-temperature thermal insulation is wrapped around the heaters and covered with an aluminum skin. 


\section{CONDENSER}

The output from the electrolysis module is about $90 \%$ hydrogen and $10 \%$ steam on a volume basis. The output flows through a natural convection finned-tube air cooler, through the outlet dewpoint sensor and into the direct-contact condenser shown in Fig. 16. The condensate is cooled using cold house water flowing through a copper coil placed inside the condenser. The level in the condenser is controlled by the height of the overflow tube which allows the condensate to flow to the condensate tank. The output steam/hydrogen stream is introduced into the condensate just below the surface. A small insertion depth is required to minimize backpressure in the electrolysis module. The hydrogen then flows from the top of the condenser, through the mass flow meter and out the hydrogen vent. The level in the condensate tank is monitored using a differential pressure transducer with one port connected to the bottom of the tank and the other open to atmosphere. At a predetermined level, a solenoid valve opens and the tank is allowed to drain until a lower level is reached, at which time the valve is closed. The change in tank level as a function of time is used to calculate the condensate flowrate.

\section{DATA ACQUISITION AND CONTROL SYSTEM}

Much of the ILS instrumentation, data acquisition, and experiment control system was described in reference [1]. A National Instruments SCXI - USB data acquisition and control system was used to collect data and provide control signals for operation of the ILS (Fig. 17). The DACS system consisted of multichannel signal conditioning modules installed in a rack-mounted chassis. Analog-input modules amplify, isolate, filter, and multiplex input signals from thermocouples, strain gauges, and voltage and current sources. Analog output modules provide isolated voltage and current outputs for instrument control. Terminal blocks are used to connect signals to the SCXI modules Certain terminal blocks are designed to work with specific modules and provide signal conditioning for certain sensor types. For example, the terminal block used for measuring thermocouple voltages contains cold-junction compensation circuitry.

Control of the above SCXI system was implemented using a personal computer and an INLdeveloped custom program (virtual instrument) using the National Instruments LabView software. LabView software provides a graphical programming environment that allows automated test and measurement interfacing with various devices and includes hundreds of builtin analysis algorithms. The INL researchers have been using LabView for the bench-scale electrolysis DACS system. In addition to the SCXI system, the virtual instrument also coordinated communication and control of the various serial interface devices as well. The virtual instrument also provides a graphical user interface for real-time operation and control of the ILS (see Fig. 18), provided on-screen real-time graphical data representation, and logged 


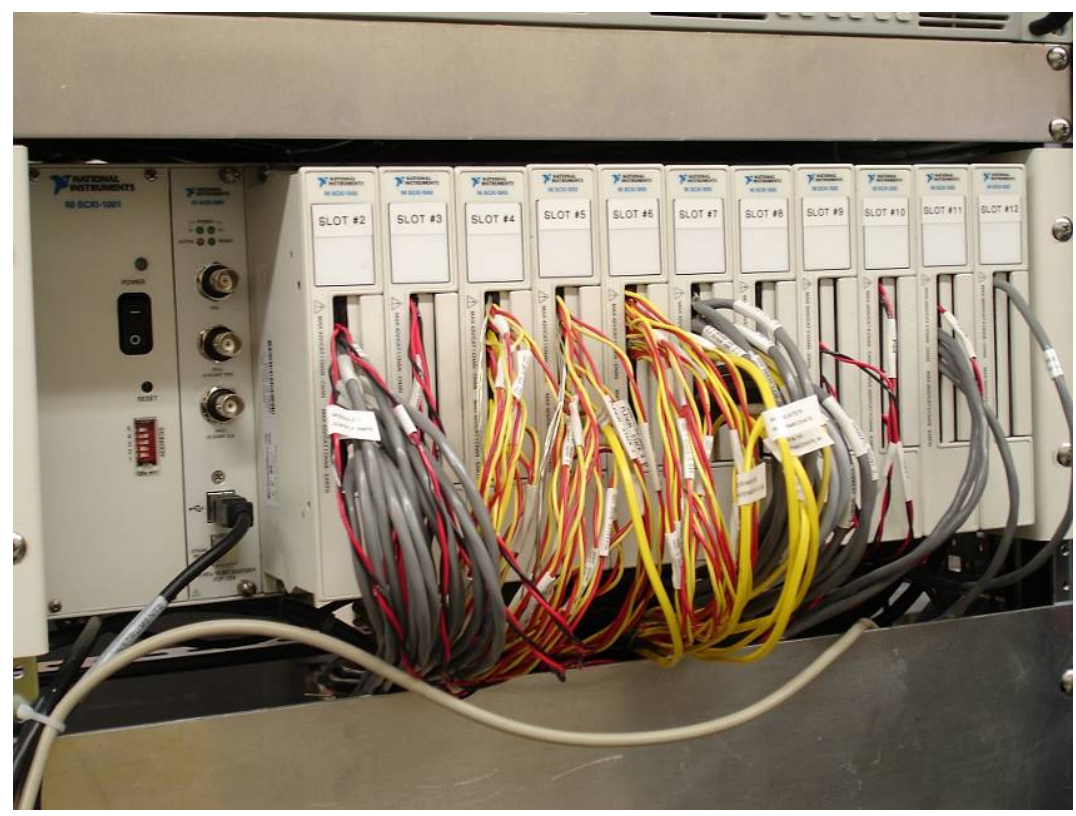

Figure 17. National Instruments SCXI-1001 data acquisition, control, and signal conditioning electronics with SCXI-1600 digital voltmeter and USB interface.

experimental test data to disk. Logged data was written in Excel spreadsheet format to simplify post-test data analysis. Table 4 lists the various input and output modules as well as connection terminal for each measurement / control signal used during the single module test.

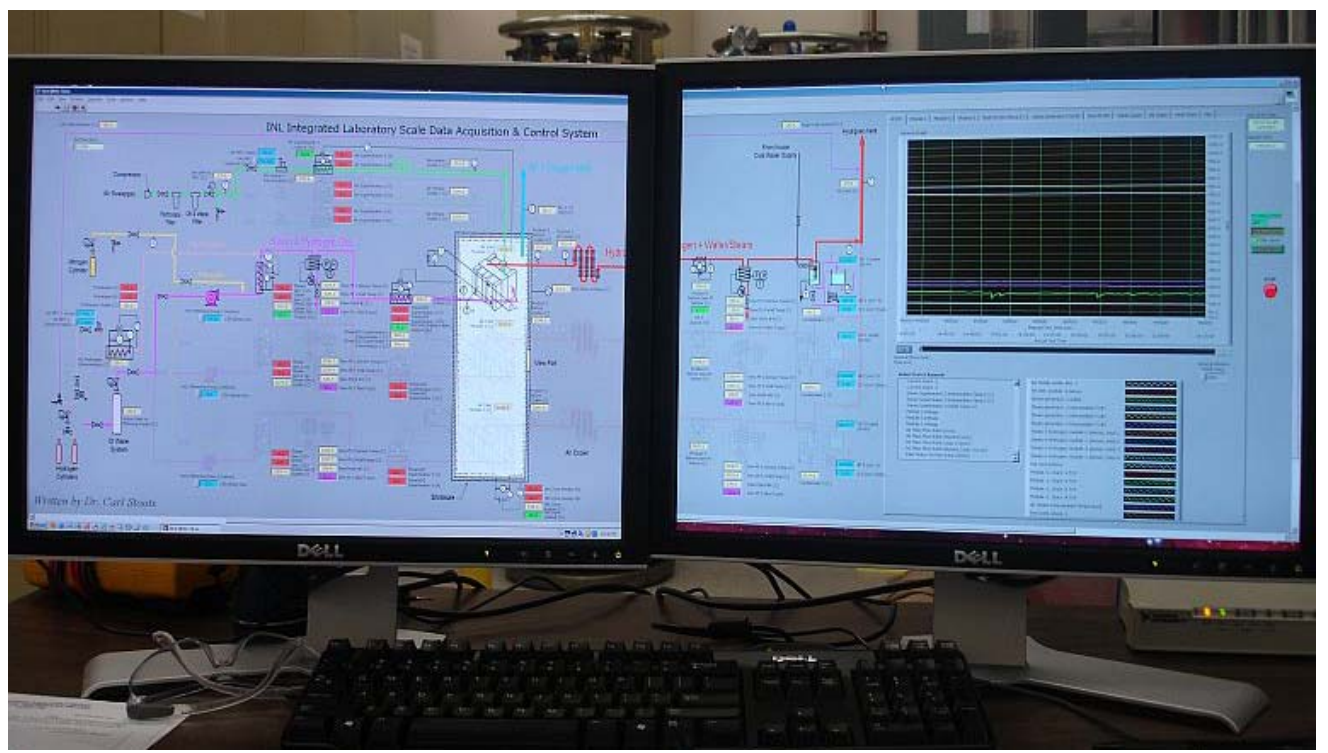

Figure 18. Screen display of the INL-developed data acquisition and control program. This program was written using the National Instruments LabView software. 
Table 4. Single module ILS data acquisition and control channel list.

\begin{tabular}{|c|c|c|c|c|c|}
\hline $\begin{array}{c}\text { SCXI } \\
\text { Slot } \\
\#\end{array}$ & Module/Terminal Block & $\begin{array}{c}\text { Module } \\
\text { Description }\end{array}$ & $\begin{array}{c}\text { Block } \\
\text { Channel } \\
\#\end{array}$ & Signal & Measurement Description \\
\hline 1 & 1600 & A to $D$ Convertor & $\mathrm{N} / \mathrm{A}$ & & \\
\hline \multirow[t]{14}{*}{2} & \multirow[t]{14}{*}{$1104 \mathrm{C} w / 1300$} & \multirow{14}{*}{$32 \mathrm{ch},+/-60 \mathrm{VDC}$} & 0 & $0-10$ VDC & Module 1 Intermediate Voltage 0 \\
\hline & & & 1 & $0-10$ VDC & Module 1 Intermediate Voltage 1 \\
\hline & & & 2 & $0-10$ VDC & Module 1 Intermediate Voltage 2 \\
\hline & & & 3 & $0-10$ VDC & Module 1 Intermediate Voltage 3 \\
\hline & & & 4 & $0-10$ VDC & Module 1 Intermediate Voltage 4 \\
\hline & & & 5 & $0-10$ VDC & Module 1 Intermediate Voltage 5 \\
\hline & & & 6 & $0-10$ VDC & Module 1 Intermediate Voltage 6 \\
\hline & & & 7 & $0-10$ VDC & Module 1 Intermediate Voltage 7 \\
\hline & & & 8 & $0-10$ VDC & Module 1 Intermediate Voltage 8 \\
\hline & & & 9 & $0-10$ VDC & Module 1 Intermediate Voltage 9 \\
\hline & & & 10 & $0-10$ VDC & Module 1 Intermediate Voltage 10 \\
\hline & & & 11 & $0-10$ VDC & Module 1 Intermediate Voltage 11 \\
\hline & & & 12 & $0-10$ VDC & Module 1 Power Supply Voltage \\
\hline & & & 13 & $0-10$ VDC & Module 1 Power Supply Amperage \\
\hline \multirow[t]{10}{*}{3} & \multirow[t]{10}{*}{$1104 \mathrm{C}$ w/ 1300} & \multirow{10}{*}{$32 \mathrm{ch},+/-60 \mathrm{VDC}$} & 10 & $0-10$ VDC & Hot zone heater power supply voltage \\
\hline & & & 11 & $0-10$ VDC & Hot zone heater power supply current \\
\hline & & & 12 & $0-10 \mathrm{VDC}$ & Air superheater 1 power supply voltage \\
\hline & & & 13 & $0-10$ VDC & Air superheater 1 power supply current \\
\hline & & & 18 & $0-10 \mathrm{VDC}$ & Steam generator 1 power supply voltage \\
\hline & & & 19 & $0-10$ VDC & Steam generator 1 power supply current \\
\hline & & & 24 & $0-10 \mathrm{VDC}$ & Steam/H2 superheater 1 power supply voltage \\
\hline & & & 25 & $0-10$ VDC & Steam/H2 superheater 1 power supply current \\
\hline & & & 30 & $0-10$ VDC & H2 preheater power supply voltage \\
\hline & & & 31 & $0-10$ VDC & H2 preheater power supply current \\
\hline \multirow[t]{12}{*}{4} & \multirow[t]{12}{*}{1102 w/ 1303} & \multirow{12}{*}{$\begin{array}{l}32 \mathrm{ch} \text { thermocouple } \\
\text { module, }+/-10 \mathrm{~V} \text { input }\end{array}$} & 0 & $\mathrm{TC}(\mathrm{K})$ & Air inlet to mass flow controllers \\
\hline & & & 1 & $\mathrm{TC}(\mathrm{K})$ & Air heater outlet, line -1 \\
\hline & & & 4 & $\mathrm{TC}(\mathrm{K})$ & Air inlet, module -1 plenum \\
\hline & & & 7 & $\mathrm{TC}(\mathrm{K})$ & Air + oxygen vent \\
\hline & & & 8 & $\mathrm{TC}(\mathrm{K})$ & Water inlet to metering pumps \\
\hline & & & 9 & $\mathrm{TC}(\mathrm{K})$ & Steam generator -1 outlet \\
\hline & & & 10 & $\mathrm{TC}(\mathrm{K})$ & Steam generator -1 intermediate TC\#1 \\
\hline & & & 11 & $\mathrm{TC}(\mathrm{K})$ & Steam generator -1 intermediate TC\#2 \\
\hline & & & 12 & $\mathrm{TC}(\mathrm{K})$ & Steam generator -1 intermediate TC\#3 \\
\hline & & & 21 & $\mathrm{TC}(\mathrm{K})$ & Hydrogen heater outlet \\
\hline & & & 22 & $\mathrm{TC}(\mathrm{K})$ & Dew point sensor -1 \\
\hline & & & 25 & $\mathrm{TC}(\mathrm{K})$ & Dew point sensor -1 , cannister wall temperature \\
\hline \multirow[t]{14}{*}{5} & \multirow[t]{14}{*}{$1102 \mathrm{w} / 1303$} & \multirow{14}{*}{$\begin{array}{l}32 \text { ch thermocouple } \\
\text { module, }+/-10 \mathrm{~V} \text { input }\end{array}$} & 0 & $\mathrm{TC}(\mathrm{K})$ & Steam + hydrogen, module -1 plenum, stack 1 \\
\hline & & & 1 & $\mathrm{TC}(\mathrm{K})$ & Steam + hydrogen, module -1 plenum, stack 2 \\
\hline & & & 2 & $\mathrm{TC}(\mathrm{K})$ & Steam + hydrogen, module -1 plenum, stack 3 \\
\hline & & & 3 & $\mathrm{TC}(\mathrm{K})$ & Steam + hydrogen, module -1 plenum, stack 4 \\
\hline & & & 12 & $\mathrm{TC}(\mathrm{K})$ & Product outlet before cooler, line -1 \\
\hline & & & 15 & $\mathrm{TC}(\mathrm{K})$ & Product outlet before dew point sensor -4 , line -1 \\
\hline & & & 18 & $\mathrm{TC}(\mathrm{K})$ & Dew point sensor -4 \\
\hline & & & 21 & $\mathrm{TC}(\mathrm{K})$ & Dew point sensor -4 , cannister wall temperature \\
\hline & & & 24 & $\mathrm{TC}(\mathrm{K})$ & Condenser -1 tank liquid \\
\hline & & & 27 & $\mathrm{TC}(\mathrm{K})$ & Hydrogen vent \\
\hline & & & 28 & $\mathrm{TC}(\mathrm{K})$ & Hot zone interior \\
\hline & & & 29 & $\mathrm{TC}(\mathrm{K})$ & Hot zone surface \\
\hline & & & 30 & $\mathrm{TC}(\mathrm{K})$ & H2/Steam @ cooler \\
\hline & & & 31 & $\mathrm{TC}(\mathrm{K})$ & H2 Preheater Intermediate Temperature \\
\hline
\end{tabular}


Table 4. Single module ILS data acquisition and control channel list (cont'd).

\begin{tabular}{|c|c|c|c|c|c|}
\hline $\begin{array}{c}\text { SCXI } \\
\text { Slot } \\
\#\end{array}$ & Module/Terminal Block & $\begin{array}{c}\text { Module } \\
\text { Description }\end{array}$ & $\begin{array}{c}\text { Block } \\
\text { Channel } \\
\#\end{array}$ & Signal & Measurement Description \\
\hline \multirow[t]{12}{*}{6} & \multirow[t]{12}{*}{$1102 \mathrm{w} / 1303$} & \multirow{12}{*}{$\begin{array}{l}32 \text { ch thermocouple } \\
\text { module, }+/-10 \vee \text { input }\end{array}$} & 0 & $\mathrm{TC}(\mathrm{K})$ & Module -1, Stack -1 TOP \\
\hline & & & 1 & $\mathrm{TC}(\mathrm{K})$ & Module -1, Stack -1 MIDDLE \\
\hline & & & 2 & $\mathrm{TC}(\mathrm{K})$ & Module -1 , Stack -1 BOTTOM \\
\hline & & & 3 & $\mathrm{TC}(\mathrm{K})$ & Module -1, Stack -2 TOP \\
\hline & & & 4 & $\mathrm{TC}(\mathrm{K})$ & Module -1, Stack -2 MIDDLE \\
\hline & & & 5 & $\mathrm{TC}(\mathrm{K})$ & Module -1, Stack -2 BOTTOM \\
\hline & & & 6 & $\mathrm{TC}(\mathrm{K})$ & Module -1, Stack -3 TOP \\
\hline & & & 7 & $\mathrm{TC}(\mathrm{K})$ & Module -1, Stack -3 MIDDLE \\
\hline & & & 8 & $\mathrm{TC}(\mathrm{K})$ & Module -1, Stack -3 BOTTOM \\
\hline & & & 9 & $\mathrm{TC}(\mathrm{K})$ & Module -1, Stack -4 TOP \\
\hline & & & 10 & $\mathrm{TC}(\mathrm{K})$ & Module -1, Stack -4 MIDDLE \\
\hline & & & 11 & $\mathrm{TC}(\mathrm{K})$ & Module -1 , Stack -4 BOTTOM \\
\hline \multirow[t]{14}{*}{7} & \multirow[t]{14}{*}{1102 w/ 1303} & \multirow{14}{*}{$\begin{array}{l}32 \mathrm{ch} \text { thermocouple } \\
\text { module, +/-10 V input }\end{array}$} & 4 & $\mathrm{TC}(\mathrm{K})$ & Test skid right side ambient \\
\hline & & & 5 & $\mathrm{TC}(\mathrm{K})$ & Test skid left side ambient \\
\hline & & & 6 & $\mathrm{TC}(\mathrm{K})$ & Air Heater Intermediate Temp \\
\hline & & & 7 & SCCM & Hydrogen outlet line -1 \\
\hline & & & 10 & $\mathrm{dP}$ & Water drain line dP -1 \\
\hline & & & 13 & Pressure & Dew point sensor absolute $\mathrm{P}-1$ \\
\hline & & & 16 & Pressure & Dew point sensor absolute $\mathrm{P}-4$ \\
\hline & & & 19 & Pressure & Enclosure absolute $\mathrm{P}$ \\
\hline & & & 20 & T dew point & Dew point sensor -1 \\
\hline & & & 23 & T dew point & Dew point sensor -4 \\
\hline & & & 26 & Amps & Current shunt -1 \\
\hline & & & 29 & $\mathrm{TC}(\mathrm{K})$ & Steam Superheater 1 Intermediate Temperature 1 \\
\hline & & & 30 & TC $(\mathrm{K})$ & Steam Superheater 1 Intermediate Temperature 2 \\
\hline & & & 31 & $\mathrm{TC}(\mathrm{K})$ & Steam Super heater 1 Outlet \\
\hline \multirow[t]{4}{*}{8} & \multirow[t]{4}{*}{$1124 w / 1325$} & \multirow{4}{*}{$\begin{array}{c}6 \mathrm{ch} \text { isolated analog } \\
\text { output, } 0-1 \mathrm{~V},+/-1 \mathrm{~V}, 0- \\
5 \mathrm{~V},+/-5 \mathrm{~V}, 0-10 \mathrm{~V},+/- \\
10 \mathrm{~V}, 0-20 \mathrm{~mA}\end{array}$} & 0 & $4-20 \mathrm{~mA}$ & Dew Pt 1 \\
\hline & & & 1 & $4-20 m A$ & Dew Pt 4 \\
\hline & & & 2 & 4-20mA & Pump 1 \\
\hline & & & 5 & $0-10$ VDC & PS1 \\
\hline \multirow[t]{2}{*}{9} & \multirow[t]{2}{*}{$1124 w / 1325$} & \multirow[b]{2}{*}{$\begin{array}{c}6 \mathrm{ch} \text { isolated analog } \\
\text { output, } 0-1 \mathrm{~V},+/-1 \mathrm{~V}, 0- \\
5 \mathrm{~V},+/-5 \mathrm{~V}, 0-10 \mathrm{~V},+/- \\
10 \mathrm{~V}, 0-20 \mathrm{~mA}\end{array}$} & 0 & $0-10$ VDC & PS2 \\
\hline & & & 3 & $0-10$ VDC & PS5 \\
\hline \multirow[t]{4}{*}{10} & \multirow[t]{4}{*}{1124 w/ 1325} & \multirow{4}{*}{$\begin{array}{c}6 \mathrm{ch} \text { isolated analog } \\
\text { output, } 0-1 \mathrm{~V},+/-1 \mathrm{~V}, 0- \\
5 \mathrm{~V},+/-5 \mathrm{~V}, 0-10 \mathrm{~V},+/- \\
10 \mathrm{~V}, 0-20 \mathrm{~mA}\end{array}$} & 0 & $0-10$ VDC & PS8 \\
\hline & & & 3 & $0-10$ VDC & PS11 \\
\hline & & & 4 & $0-10$ VDC & PS12 \\
\hline & & & 5 & $0-10$ VDC & PS13 \\
\hline \multirow[t]{3}{*}{11} & \multirow[t]{3}{*}{$1124 \mathrm{w} / 1325$} & \multirow{3}{*}{$\begin{array}{c}6 \mathrm{ch} \text { isolated analog } \\
\text { output, } 0-1 \mathrm{~V},+/-1 \mathrm{~V}, 0- \\
5 \mathrm{~V},+/-5 \mathrm{~V}, 0-10 \mathrm{~V},+/- \\
10 \mathrm{~V}, 0-20 \mathrm{~mA}\end{array}$} & 0 & $0-10$ VDC & PS14 \\
\hline & & & 1 & $0-10$ VDC & Condenser valve \\
\hline & & & 2 & 4-20mA & Heat trace to dew point 4 \\
\hline 12 & 1125 w/ 1327 & $\begin{array}{c}8 \mathrm{ch} \text { high voltage input, } \\
+/-250 \mathrm{~V}\end{array}$ & 0 & Volts & Module -1 \\
\hline
\end{tabular}




\section{SHAKEDOWN EXPERIMENT}

Initial facility operation was conducted in late August to check out the ILS system, individual component operation, instrumentation, control, and startup procedures. This test series did not include the electrolysis module. The inlet and outlet streams were simply connected with a tube inside the hot zone. Nitrogen gas was injected into the steam superheater to simulate the hydrogen inlet flow. In order to meet the DOE Level 2 milestone requirements for this test, the following criteria had to have been met:

- ILS fully assembled for operation with a single module - excluding the installation of the first electrolyzer module in the hot zone

- Safety requirements have been implemented

- All necessary instrumentation installed for operation with a single module and ready for initial operation

- Skid capable of providing steam, hydrogen and sweep gas at required temperature (800 $\left.850^{\circ} \mathrm{C}\right)$

- Hot zone capable of reaching $850^{\circ} \mathrm{C}$

- LabView software capable of controlling the experiment and recording data

- Power supplies connected and capable of providing necessary voltage and amperage (may be pre-tested with a load resistor).

"Begin operations" was defined as when the following conditions were simultaneously met:

- The hot zone is at the cell operating temperature $\left(>800^{\circ} \mathrm{C}\right)$

- The steam generator / superheater combination is producing steam at $>800^{\circ} \mathrm{C}$. Air heater is producing hot air at $>800^{\circ} \mathrm{C}$.

- A $90 \%$ steam, $10 \% \mathrm{H}_{2}$ mixture at $>800^{\circ} \mathrm{C}$ is flowing, at 60 normal liters $/ \mathrm{min}$, and heated air at 23 normal liters per minute, into the hot zone and out through the coolers and the condenser unit. The hot air will flow into the interior of the hot zone. The steam flow rate corresponds to a water flow rate of $40 \mathrm{gm} / \mathrm{min}$.

A representative of DOE-ID attended the initial experimental operations of the ILS. The ILS skid met all of the above components and definitions with the following specific temperatures and flow rates at 10:30 am Wednesday, August 22, 2007.

- The output of the steam generator was $140^{\circ} \mathrm{C}$

- The output of the steam superheater as $824^{\circ} \mathrm{C}$

- The hot zone (i.e. stack test chamber) as $859^{\circ} \mathrm{C}$

- The $\mathrm{H}_{2}$ flow into the hot zone was 6 standard liters per minute (slpm)

- The steam flow into hot zone was 54 slpm. (Steam and $\mathrm{H}_{2}$ combined in a 60 slpm flow at $90 \%$ steam and $10 \% \mathrm{H}_{2}$ )

- Air flow into the hot zone was 24 slpm

- The air temperature at the exit from the air heater was $855^{\circ} \mathrm{C}$

- The water flow into the steam generator was $42 \mathrm{ml} / \mathrm{min}$.

- The output of the steam generator and superheater was relatively stable. 
The results of this experiment were also used to determine the parameters for the PID controllers used to control the power to the various components.

\section{SINGLE MODULE STARTUP SEQUENCE}

The following is the sequence of steps followed by the researchers to heat up the ILS to operating conditions.

1.) Walk down system. Ensure tools and spurious equipment/supplies have been removed from the skid.

2.) Conduct pre-test briefing.

3.) Connect hydrogen bottles and nitrogen bottle to system. Check output pressures of cylinders. Replace cylinders if necessary.

4.) Put into position all necessary warning signs and administrative barriers.

5.) Notify all personal in bay that testing is about to commence.

6.) Ensure that system is ready for removal of lock out / tag out. Remove lock out / tag out. Don necessary PPE and energize system.

7.) Check that all appropriate circuit breakers are in "ON" position.

8.) Turn on all necessary power supplies.

9.) Turn on Teledyne Hastings power supply/read out units.

10.) Turn on data acquisition and control (DAC) computer and SCXI system.

11.) Check DAC values for thermocouples and voltages/currents.

12.) Check output pressure of deionized water system to ensure output pressure is between 5 and 10 psi gauge.

13.) Double check that no spurious items are in hot zone. Visually check module. Photograph module if desired. Ensure hot zone gasket is in place. Lower hot zone lid.

14.) Start flow of cooling water to small and large condenser.

15.) Ensure water level in condenser is appropriate.

16.) Fill steam generator up to within the forced convection / vaporization regime height. Check in sight tube. Stop metering pump.

17.) Heatup profile for the initial module will be the following:

a. From room temperature up to $400^{\circ} \mathrm{C}$, pure dry nitrogen at $50 \%$ of target flow. $50 \%$ of target flow is $2.5 \mathrm{Nl} / \mathrm{min}$.

b. From $400^{\circ} \mathrm{C}$ to $600^{\circ} \mathrm{C}, \mathrm{N}_{2} / \mathrm{H}_{2}$ dry at $50 \%$ target flows. $50 \%$ of target flows is 2.5 $\mathrm{Nl} / \mathrm{min}, 2.5 \mathrm{Nl} / \mathrm{min}$, respectively.

c. From $600^{\circ} \mathrm{C}$ to $800^{\circ} \mathrm{C}, \mathrm{N}_{2} / \mathrm{H}_{2}$ at $50 \%$ target flows with $\sim 3 \% \mathrm{H}_{2} \mathrm{O}$. $3 \% \mathrm{H}_{2} \mathrm{O}$ corresponds to a dewpoint of $21.7^{\circ} \mathrm{C}$. This dewpoint is not critical.

18.) Set valving such that nitrogen and hydrogen flows are introduced downstream of the steam generator but upstream of dew point sensor \#1.

19.) Start writing data to disk.

20.) Initiate $\mathrm{N}_{2}$ flow at approximately $50 \%$ of target flow, per above.

21.) Initiate air flow rate to $20 \mathrm{Nl} / \mathrm{min}$ for heatup.

22.) Set steam $/ \mathrm{H}_{2}$ superheater to ramp from $20^{\circ} \mathrm{C}$ to $800^{\circ} \mathrm{C}$ in $0.06^{\circ} \mathrm{C} /$ step increment (DAS is $\sim 1.7 \mathrm{sec} / \mathrm{step}$, thus $2^{\circ} \mathrm{C} /$ minute). Set air superheater to ramp from $20^{\circ} \mathrm{C}$ to $800^{\circ} \mathrm{C}$ in $0.06^{\circ} \mathrm{C} /$ step increment. Set hot zone heater ramp from $20^{\circ} \mathrm{C}$ to $800^{\circ} \mathrm{C}$ in $0.06^{\circ} \mathrm{C} /$ step increment. 
23.) Gradually increase setpoint temperatures for inlet and outlet Vaisalas dewpoint sensor from room temperature ultimately to $110^{\circ} \mathrm{C}$, such that temperature overshoot is minimized.

24.) Set setpoint of heat trace to ultimately to $110^{\circ} \mathrm{C}$, but gradually to minimize overshoot.

25.) Ensure the steam $/ \mathrm{H}_{2}$ superheater, air superheater, and hot zone all are increasing uniformly to avoid thermal shock to stack. Note that hot zone will heat much faster than the superheaters.

26.) Once $400^{\circ} \mathrm{C}$ is achieved, maintain $\mathrm{N}_{2}$ flow and initiate $\mathrm{H}_{2}$ flow downstream of steam generator but upstream of inlet dew point sensor.

27.) Set $\mathrm{H}_{2}$ preheater to manual control.

28.) Gradually start increasing power level to $\mathrm{H}_{2}$ preheater until a stable $\sim 130^{\circ} \mathrm{C}$ outlet temperature is achieved.

29.) Resume heatup from $400^{\circ} \mathrm{C}$ to $600^{\circ} \mathrm{C}$ with dry $\mathrm{N}_{2} / \mathrm{H}_{2}$ mixture.

30.) Once $600^{\circ} \mathrm{C}$ is achieved, maintain $\mathrm{H}_{2}$ flow and valving. Redirect $\mathrm{N}_{2}$ gas inlet from downstream of steam generator to upstream of steam generator. Note that steam generator is at room temperature. Now, $\mathrm{N}_{2}$ is flowing through partially full steam generator and is then mixed with preheated $\mathrm{H}_{2}$ before entering dew point sensor.

31.) Resume heatup from 600 to $800^{\circ} \mathrm{C}$.

\section{GENERAL RESULTS}

Operation and performance of each major component of the ILS is discussed in detail in the following sections. Recommendations on how the design or operation of these components may be improved for future experiments to enhance the overall performance of the ILS are presented.

On many of the data plots shown in the following sections an anomaly in the data is observed in the time range of 213 to 239 hours after initiation of the experiment. This anomaly was caused by the failure of one of the intermediate stack thermocouples at 213 hours which imposed a bias voltage on the data acquisition system. Confirmation of the anomaly was made by removing selected channels from the data acquisition system and measuring the output with instruments independent of the data system. The effect of this bias voltage on the recorded data was dependant on the type and location of the measurement. At 239 hours all of the stack intermediate thermocouple and cell voltage data channels were removed from the data acquisition system and the system data recording returned to normal.

Sharp spikes can be seen in the data traces at approximately $25,40,65,120,230$, and 260 hours. These are due to stopping and restarting the DACS. Usually this was done in order to make a minor software change such as increasing the significant figures of a particular digital display or adding a digital display to the front panel.

\section{ELECTROLYSIS MODULE - TRANSIENT HEATUP AND FIRST 50 HOURS}

Heatup of the first ILS module started at approximately 4:10 PM on September 24, 2007. Fig. 19 presents the hot zone and stack internal temperatures for the heatup period as well as the initial sweep discussed below. Steps in the hot zone temperature correspond to points in the heatup procedure where changes in gas flow settings were made. 
The hot zone cool-down between 6 and 9 hours elapsed test time was due to installation of a computeroperated relay to disengage the ILS module power supply from the module. To accurately measure the open cell potential of the ILS module, the module must be in the open-circuit condition. Furthermore, installation of the relay reduces the chances of accidentally allowing the module to operate in fuel cell mode, with the power supply serving as a current sink.

The second large data interruption between approximately 18 and 26 hours elapsed test time was due to installation of new clamp heaters on the steam generator. Several internal stack thermocouples were lost at approximately 17 hours as well.

Finally, there is a slight internal stack temperature excursion at approximately 33 to 38 hours elapsed test time. Some steam condensate formed in an uninsulated line leading from the hot zone steam $/ \mathrm{H}_{2}$ outlet to the product cooler. This condensate eventually imposed a backpressure upon the module, causing some $\mathrm{H}_{2}$ to leak and subsequently combust (at operating temperature, the hot zone is well above the auto-ignition temperature of hydrogen, so any mixing of hydrogen and air results in a diffusion flame). The heat of combustion, in turn, forced a module temperature increase. Since ASR is inversely related to temperature, the increased operating

Table 5. Operating conditions for ILS module voltage sweep.

\begin{tabular}{|l|c|}
\hline Hot zone temperature & $820 \mathrm{C}$ \\
\hline Inlet water mass flow rate & $34 \mathrm{ml} / \mathrm{min}$ \\
\hline Inlet $\mathrm{H}_{2}$ flow rate & $5.4 \mathrm{Nl} / \mathrm{min}$ \\
\hline Inlet $\mathrm{N}_{2}$ flow rate & $5.4 \mathrm{Nl} / \mathrm{min}$ \\
\hline Inlet Air flow rate & $25 \mathrm{Nl} / \mathrm{min}$ \\
\hline Predicted OCV & $50.5 \mathrm{~V}$ \\
\hline Measured OCV & $49.6 \mathrm{~V}$ \\
\hline Predicted inlet dew point & $90.3 \mathrm{C}$ \\
\hline Measured inlet dew point & $91.3 \mathrm{C}$ \\
\hline Outlet dew point at OCV & $90.2 \mathrm{C}$ \\
\hline
\end{tabular}

temperature reduced the effective ASR and allowed greater electrical current throughput and higher $\mathrm{H}_{2}$ production. During the temperature excursion, internal module temperatures approached $900^{\circ} \mathrm{C}$ and the module $\mathrm{H}_{2}$ production rate peaked at over 2 $\mathrm{Nm}^{3} / \mathrm{hr}$. Lowering the module electrolysis voltage reduced the internal temperatures. Addition of insulation to the line eliminated the condensate problem in that part of the ILS system. Nonetheless, care must be taken when first introducing steam to the module that the product line temperature is high enough to avoid condensation. 


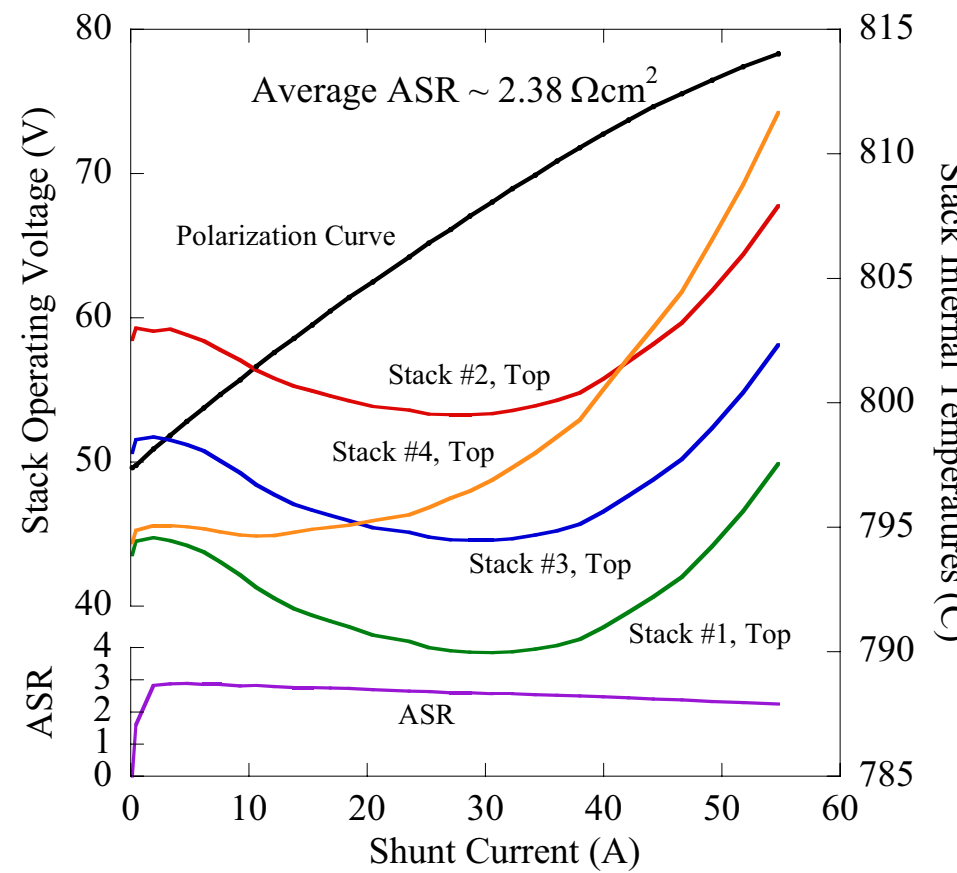

Figure 20. ILS module voltage sweep / polarization curve data.

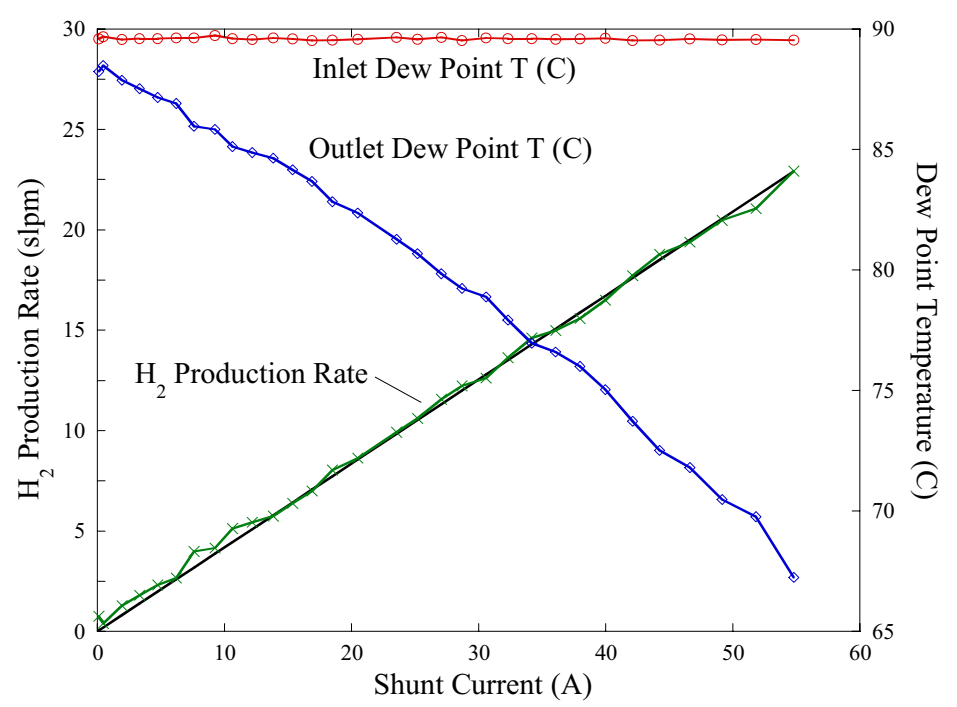

Figure 21. ILS module voltage sweep hydrogen production rates and dew points.

\section{ELECTROLYSIS MODULE - INITIAL SWEEP}

At approximately 7:20 PM on September 25, 2007, the ILS module performance was tested by sweeping the module power supply voltage over the range of 50 to 79 $\mathrm{V}(0.83 \mathrm{~V} /$ cell to $1.32 \mathrm{~V} / \mathrm{cell})$. This range corresponds to operation from the open-cell voltage to slightly above the thermal neutral voltage. The operating conditions for the ILS module voltage sweep are listed in Table 5. The corresponding voltage / current (VI) or polarization curve is displayed in Fig. 20. The average ASR for the initial ILS module, represented by the average slope of the VI curve,

was measured to be $2.38 \Omega \mathrm{cm}^{2}$. This value was significantly higher than the design value of $1.5 \Omega \mathrm{cm}^{2}$, but was not unexpected. Subcontractor Cermatec Inc, the manufacturer of the ILS module, had forewarned INL to expect lower performance from this particular module due to manufacturing difficulties they had encountered. After testing samples of newly manufactured cells between March and August of 2007, Ceramatec assures INL that these problems have been solved and future modules should exhibit higher performance.

Stack internal temperatures initially decreased during the voltage sweep, due to the endothermic heat of reaction for water splitting. Once the operating voltage exceeded the thermal neutral voltage (77V for 60 cells), outlet gas temperatures exceeded inlet values.

Fig. 21 presents inlet and outlet dewpoint temperatures and hydrogen production rate for the ILS initial single-module sweep. The inlet gas dew point remained essentially constant at $89.6^{\circ} \mathrm{C}$ throughout the duration of the sweep. The outlet stream dew point temperature decreased continuously through the sweep as the operating voltage and stack current increased. The 
straight black line in Fig. 21 represents the hydrogen production rate based on electrolysis current, while the green trace is the hydrogen production rate based on the difference between inlet and outlet dew points. $\mathrm{H}_{2}$ production based upon dew points depends not only upon the inlet and outlet dew points, but also upon the inlet gas flow rates and absolute pressures where the dew point measurement is taken. Thus, the $\mathrm{H}_{2}$ production rate based upon dew points depends upon six independent experimental measurements, whereas $\mathrm{H}_{2}$ production estimates based upon current only rely upon one experimental measurement, namely, the electrical current. Agreement between the two independent measurements of hydrogen production was generally excellent. At the highest current levels, $\mathrm{H}_{2}$ production rates exceeded $1.5 \mathrm{Nm}^{3} / \mathrm{hr}(25 \mathrm{slpm}$ or $0.134 \mathrm{~kg}$ $\mathrm{H}_{2} / \mathrm{hr}$ ) during the sweep.

\section{ELECTROLYSIS MODULE - LONG DURATION TEST}

Table 6. Long duration operating conditions for ILS module.

\begin{tabular}{|l|c|}
\hline Hot zone temperature & $810-820 \mathrm{C}$ \\
\hline Inlet water mass flow rate & $34 \mathrm{ml} / \mathrm{min}$ \\
\hline Inlet $\mathrm{H}_{2}$ flow rate & $5.4 \mathrm{Nl} / \mathrm{min}$ \\
\hline Inlet $\mathrm{N}_{2}$ flow rate & $5.4 \mathrm{Nl} / \mathrm{min}$ \\
\hline Inlet Air flow rate & $25 \mathrm{Nl} / \mathrm{min}$ \\
\hline Measured inlet dew point & $91.3 \mathrm{C}$ \\
\hline Module operating voltage & $78 \mathrm{~V}$ \\
\hline
\end{tabular}

After performing a voltage sweep, the ILS operating parameters were set to the conditions listed in Table 6. Fig. 22 presents the complete time history of module voltage, current, and $\mathrm{H}_{2}$ production rate. The test was concluded after 420 hours duration. This was not due to any equipment failure. It was the opinion of the researchers that since the stack performance degradation had essentially stopped after about 250 hours, there was little more to be learned from the test.

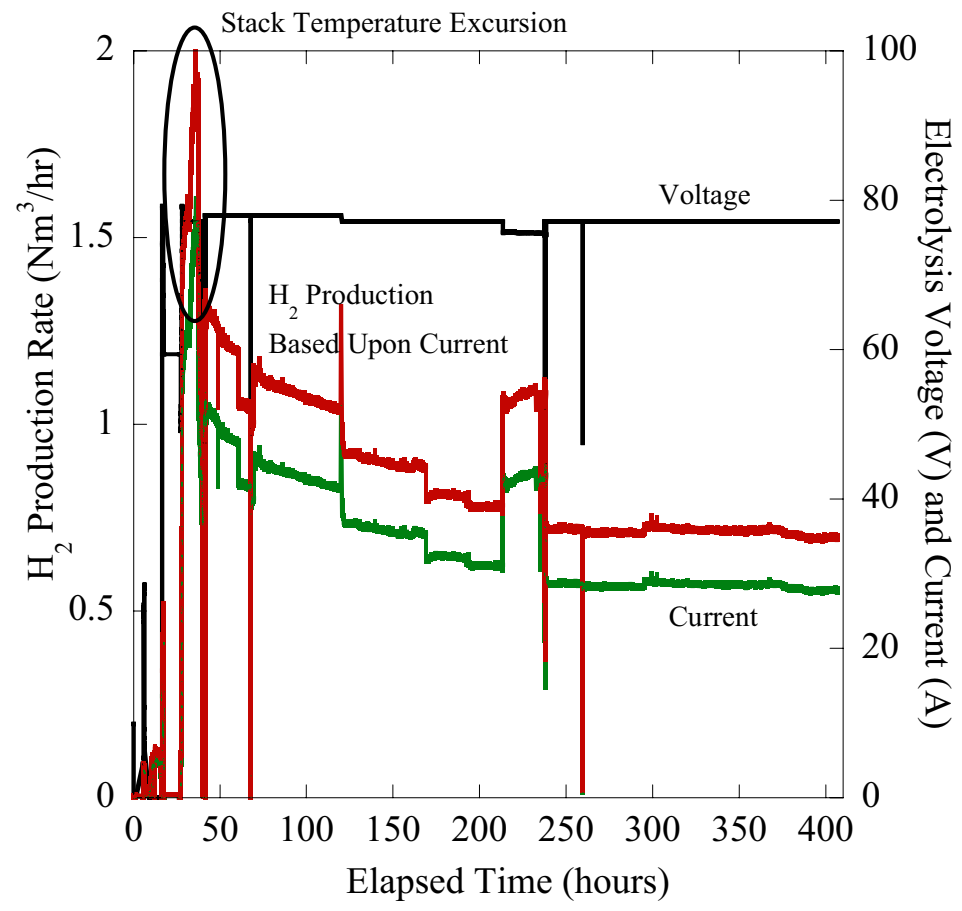

Figure 22. Complete electrical history of ILS module.
Over the period of the test, the $\mathrm{H}_{2}$ production rate dropped from over $1.5 \mathrm{Nm}^{3} / \mathrm{hr}\left(0.134 \mathrm{~kg} \mathrm{H}_{2} / \mathrm{hr}\right)$ to a steady value of $0.7 \mathrm{Nm}^{3} / \mathrm{hr}(0.0625$ $\mathrm{kg} \mathrm{H}_{2} / \mathrm{hr}$ ). Early on in the test, the module underwent a temperature excursion. Another issue that arose during the course of longduration testing concerned the intra-stack temperatures. The thermocouples inserted into the stack were 0.020 " outer diameter, inconel-sheathed, ungrounded Type K. While inserted, these thermocouples are in direct contact with the metallic air flow fields, which are at an elevated voltage potential whose magnitude is dependent upon which cell they are part of. Over time, the internal insulation of one such thermocouple deteriorated, 


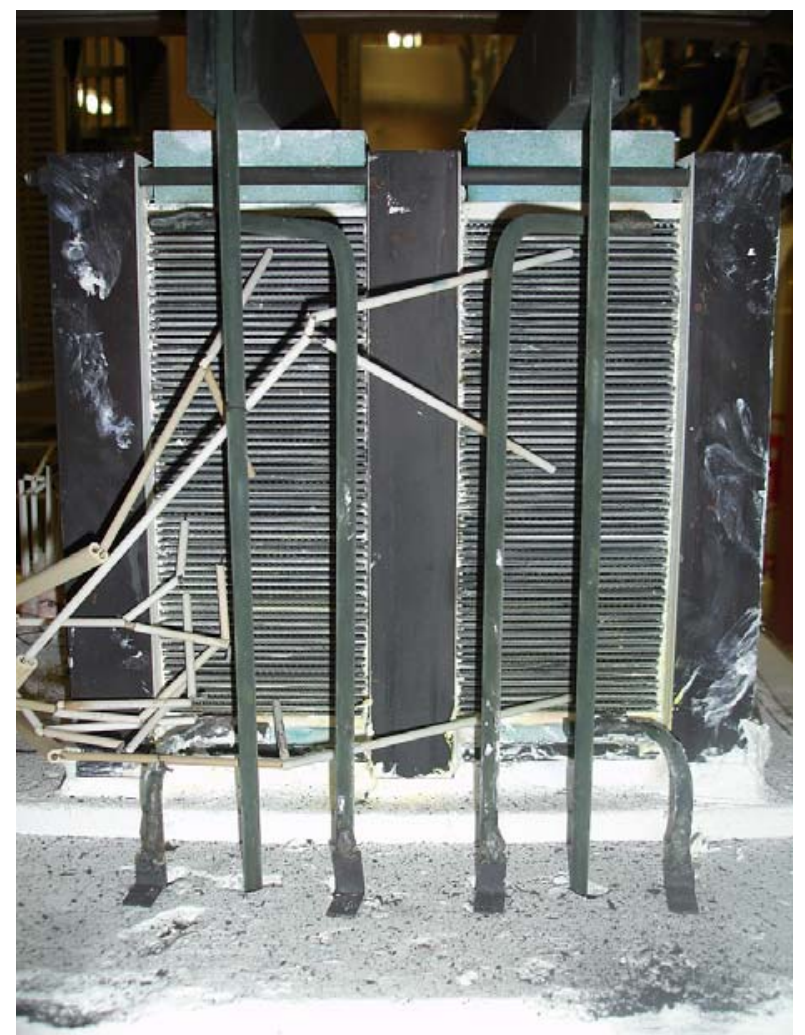

Figure 23. Post test photograph of the ILS initial module. eventually to the point that it was no longer ungrounded. When grounded, the thermocouple introduced a bias voltage into the DACS, which could be as much as $60 \mathrm{~V}$ or more. For short stack testing in the past, this was never a problem since the bias voltage would be much smaller. Such a large bias voltage affected other readings within the DACS. Eventually, all intrastack measurements were disconnected to eliminate the bias voltage from the DACS. To solve this problem in the future, a separate isolated DACS will be used for intrastack temperature measurements.

Figure 23 is a post-test photograph of the ILS initial electrolysis module after 420 hours of operation.

\section{HOT ZONE ENCLOSURE}

Once the hot zone enclosure set point temperature of $810^{\circ} \mathrm{C}$ was reached, the temperature was maintained constant by the radiant heaters mounted on the inside of the

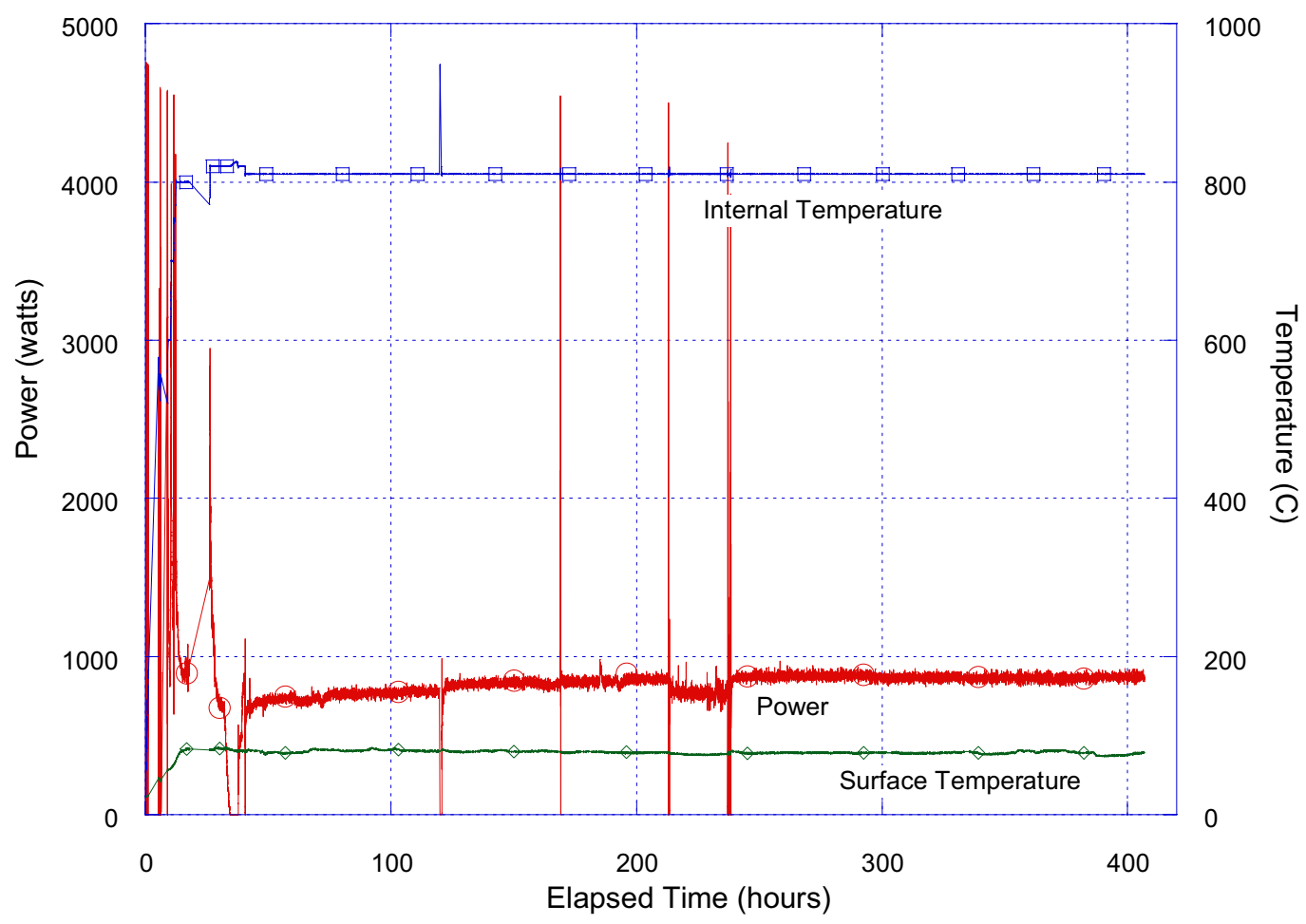

Figure 24. Hot zone steady state power, interior, and exterior surface temperature. 
enclosure lid and the control system that regulated the power to the heaters. The enclosure heaters are capable of producing approximately $15 \mathrm{~kW}$, but less than $1 \mathrm{~kW}$ was required to maintain the set point temperature. The insulation was also effective in keeping the outside surface temperature of the enclosure lid below $100^{\circ} \mathrm{C}$. Fig. 24 shows a plot of the input power to the enclosure heaters, the interior temperature, and the exterior surface temperature as a function of time.

A specified heatup rate of $100^{\circ} \mathrm{C} / \mathrm{hr}$ was achieved by the heaters and controller. Because of the large mass within the enclosure, most notably the electrolysis module, up to $4.6 \mathrm{~kW}$ was required to achieve the specified heatup rate. When the additional two electrolysis modules are installed, more power will be required during heatup.

\section{STEAM GENERATOR}

The data which characterize the performance of the steam generator are shown in Fig. 25. This plot shows that the outlet steam temperature ranged from $100^{\circ} \mathrm{C}$ to $180^{\circ} \mathrm{C}$ with essentially constant power input. This outlet temperature variation occurs because of the several heat transfer regimes within the steam generator associated with boiling and two-phase flow. Fluid enters the steam generator as subcooled water and exits as superheated steam. The power required to heat the fluid from saturated steam to the desired superheat temperature is a very small portion of the total input power to the steam generator. The steam generator was designed with a much lower heat flux in the superheat portion, but even a very small change in total input power or inlet flow conditions disturbs the flow regime profile within the entire steam generator

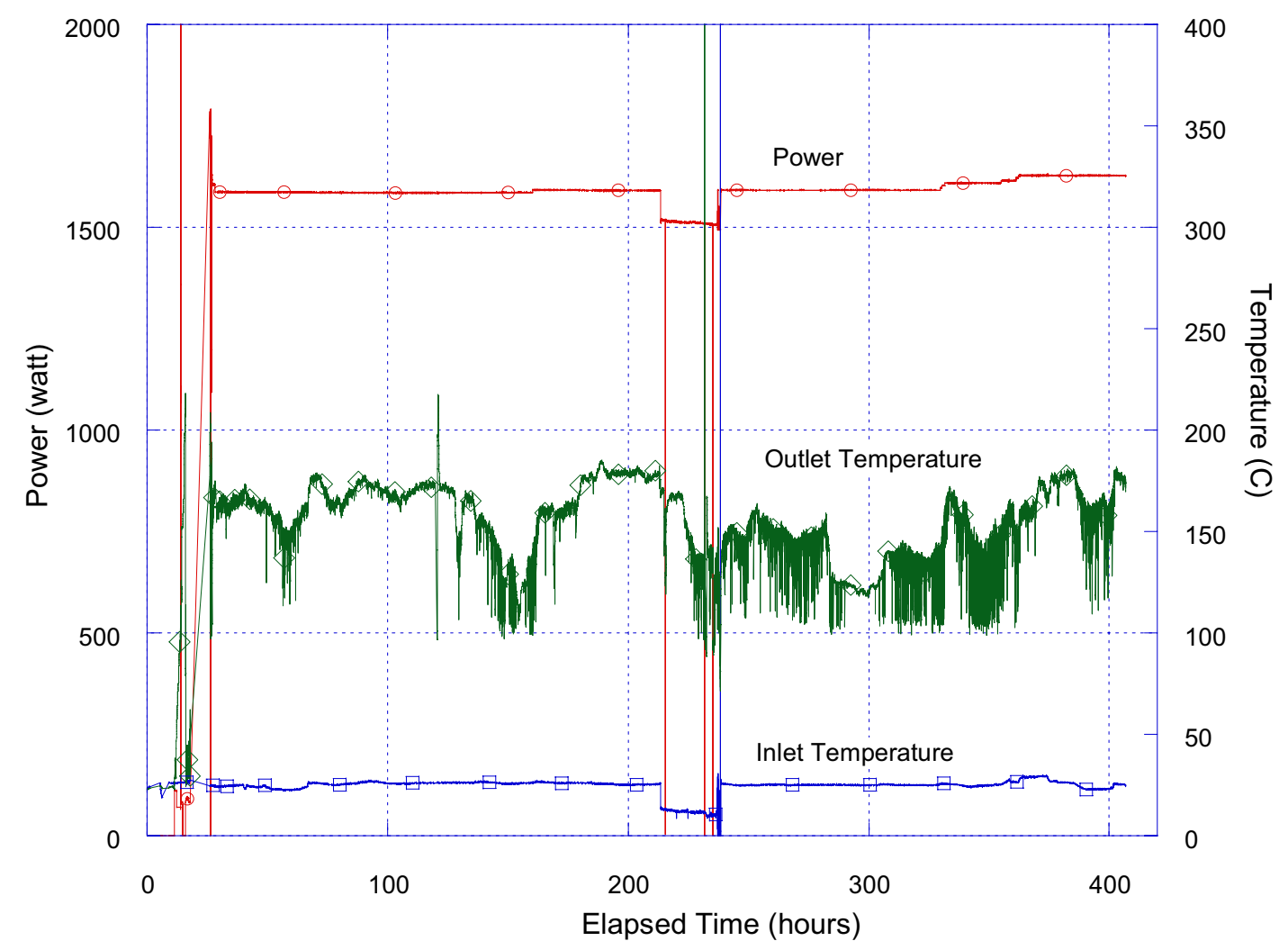

Figure 25. Steam generator performance. 


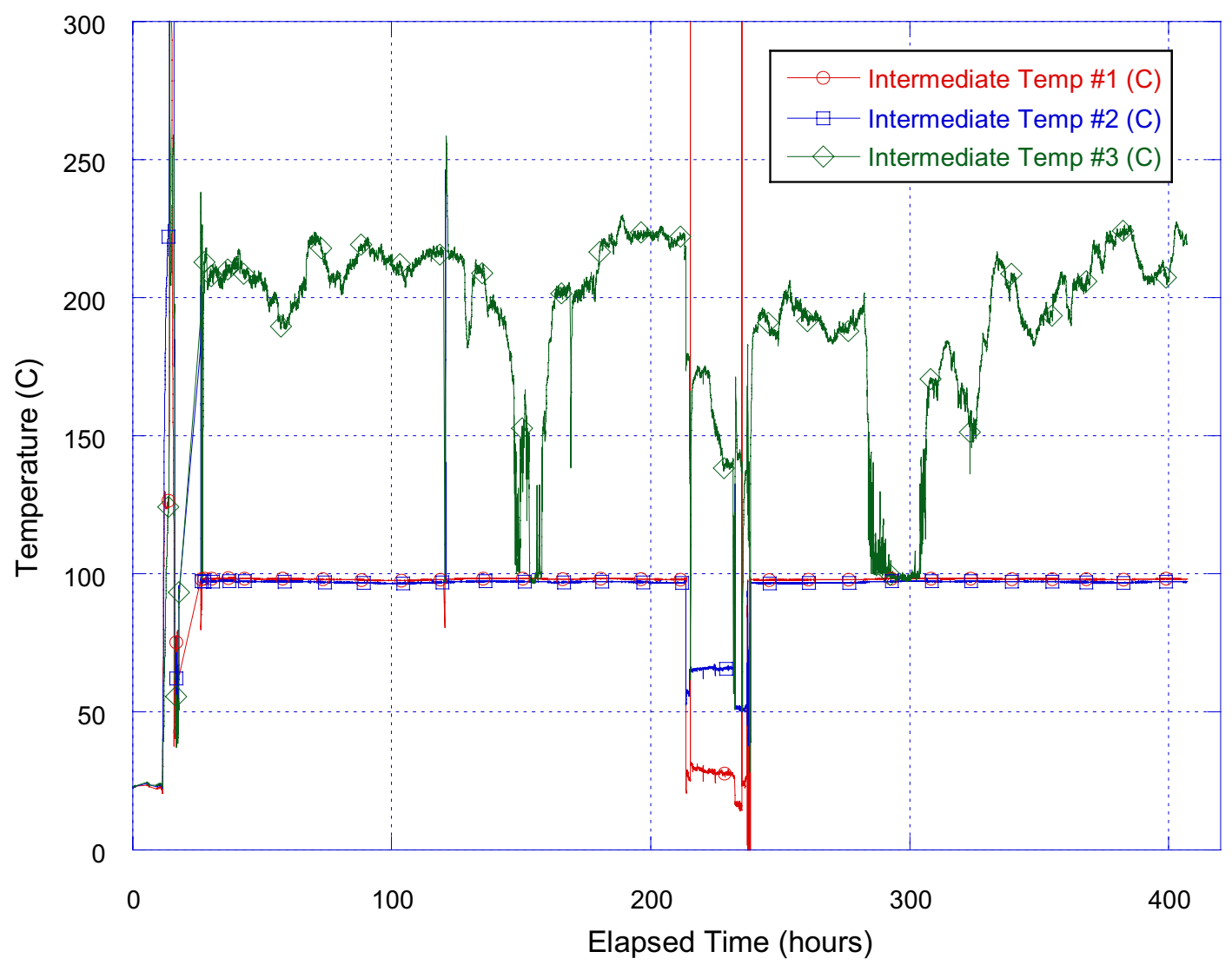

Figure 26. Steam generator internal temperatures.

tube, resulting in a relatively large change in the outlet superheat temperature. Because of this sensitivity it was impossible to control the outlet temperature using feedback based on the outlet temperature to control the input power, consequently power for this experiment was controlled manually, based on the thermodynamic requirement for heating and vaporization of the liquid.

With the exception of the control issue, the steam generator performed well. The intermediate wall temperatures, shown in Fig. 26, were well below the maximum recommended heater operating temperatures and tracked the inside fluid temperature. Heat losses were less than $10 \%$ of the total input power.

One possible modification to the steam generator that may be considered by the investigators is to divide the band heaters into two sections which are powered by two independent power supplies. The heaters on the lower portion of the steam generator tube up to the calculated point of saturated vapor would be powered by one power supply, and the heaters in the superheated region would be powered by the second power supply. The lower power supply, the larger of the two, would be controlled from a calculation based on the input water flowrate, the input water temperature, and an estimate of the heat losses which would just bring the water to a saturated vapor state based on equilibrium assumptions. The upper power supply would power only the superheated portion and would be feedback controlled from the outlet temperature. 


\section{STEAM SUPERHEATER TRANSIENT AND STEADY-STATE BEHAVIOR}

Operational data that characterize the performance of the steam superheater are shown in Fig. 27. The velocity of the steam flow inside of the steam generator pipes ranges from 5 to $15 \mathrm{~m} / \mathrm{sec}$ over the length of the pipes, but because the density is so low, the flow is still laminar and the heat transfer coefficient is very low. This fact coupled with the large metal mass of the pipes and the type of heaters used, makes the outlet temperature response to changes in input power very slow. Because of the long response time, using the outlet temperature as the control parameter for the PID power controller resulted in excessive temperatures in the heaters. To prevent heater failure, intermediate temperature \#2 was used as the control temperature with a set point of $1000^{\circ} \mathrm{C}$. The resultant outlet steam temperature was about $810^{\circ} \mathrm{C}$, which was satisfactory for the electrolysis module inlet temperature. The power oscillations shown in Fig. 27 appear to be very rapid but in fact have a period of about five minutes because of the slow response time of the heater assembly. For the time period between 120 and 160 hours, the steam superheater power was set at a steady value of $2344 \mathrm{~W}$ with no feedback. This resulted in the superheater outlet temperature variations reflecting the outlet temperature variations of the steam generator.

The low heat transfer coefficient from the pipe wall to the fluid forced the heaters to operate at higher temperatures than desired which resulted in the heat losses from the outside surface of the superheater to exceed $60 \%$ of the total power.

Clearly, improvements need to be made in the steam superheater to improve heat transfer to the fluid which will lower the heater temperature, allowing more control flexibility, and reduce the heat losses. The parameters for the PID feedback controller also need to be optimized.

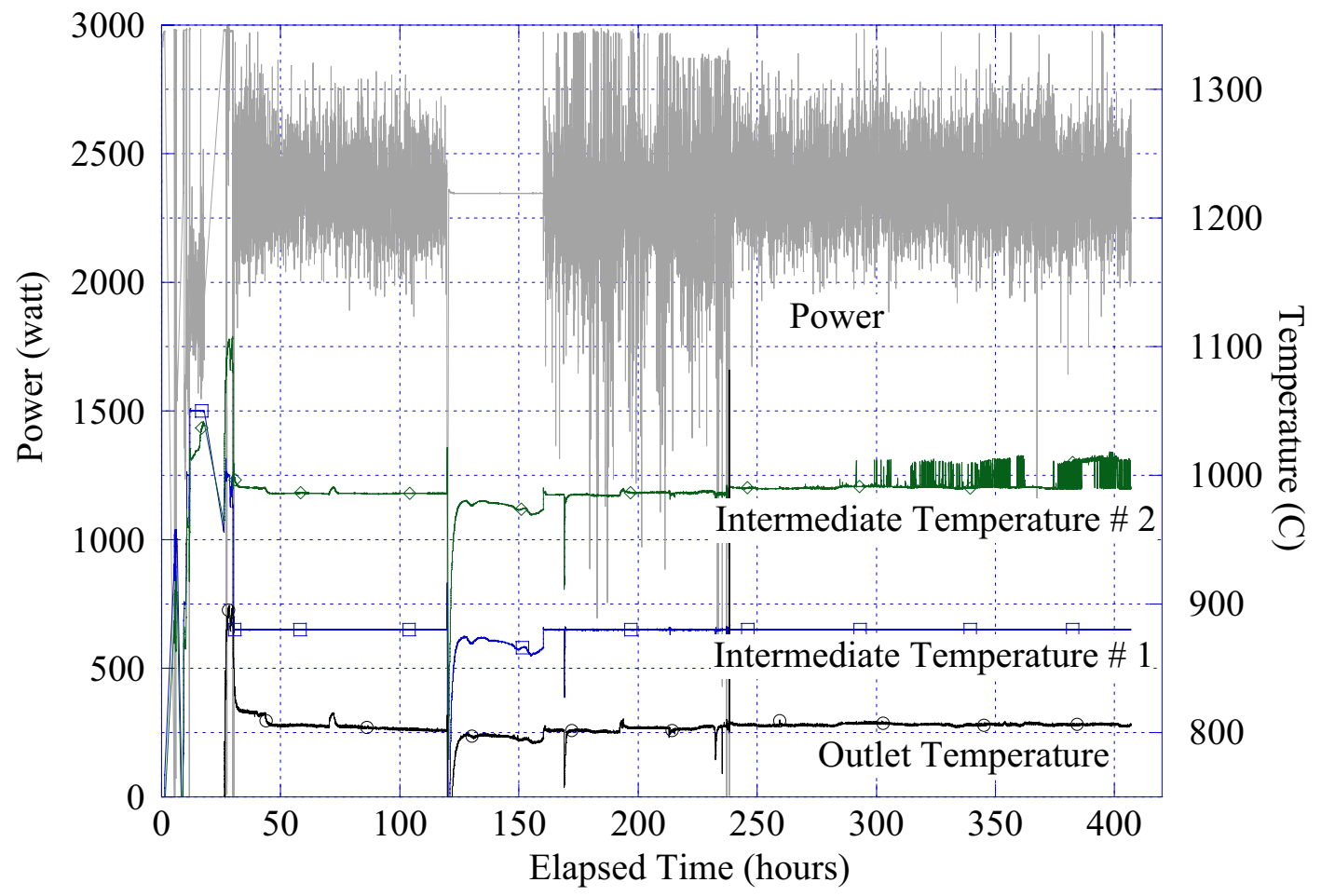

Figure 27. Steam superheater performance. 
One recommendation to increase the pipe wall heat transfer is to insert a heat transfer enhancement into the pipes that would create turbulence and increase the heat transfer coefficient. Such an insertion could also increase the surface available for heat transfer. Suggestions for the inserted material include small metal spheres, a metal foam, a coiled metal wire, or a cylindrical screen. A second recommendation is to increase the outside surface area to increase the radiant heat transfer to the tube. Controller optimization could be achieved by running the steam generator coupled with the steam superheater as separate-effects tests and just condensing the output steam instead of inputting it into the electrolysis module.

\section{AIR HEATER}

The performance of the air heater was very similar to the steam superheater in that its time response is very slow with regard to changes in power input and it has a low inside tube-to-air heat transfer coefficient. Operational data from the air heater are shown in Fig. 28.

The air flowrate to the heater was constant throughout the experiment at $25 \mathrm{slpm}$. The single intermediate thermocouple output was used as the control temperature and was set at $1050^{\circ} \mathrm{C}$ to prevent burnout of the heaters. With that constraint, the outlet temperature of the air reached only about $750^{\circ} \mathrm{C}$. At 331 hours the intermediate thermocouple failed and the power to the air heater was set at a constant 805 watts which resulted in an outlet temperature of $761^{\circ} \mathrm{C}$. The heat loss from the air heater was about $50 \%$ of the input power.

Recommendations for improvement of the air heater performance are essentially the same as

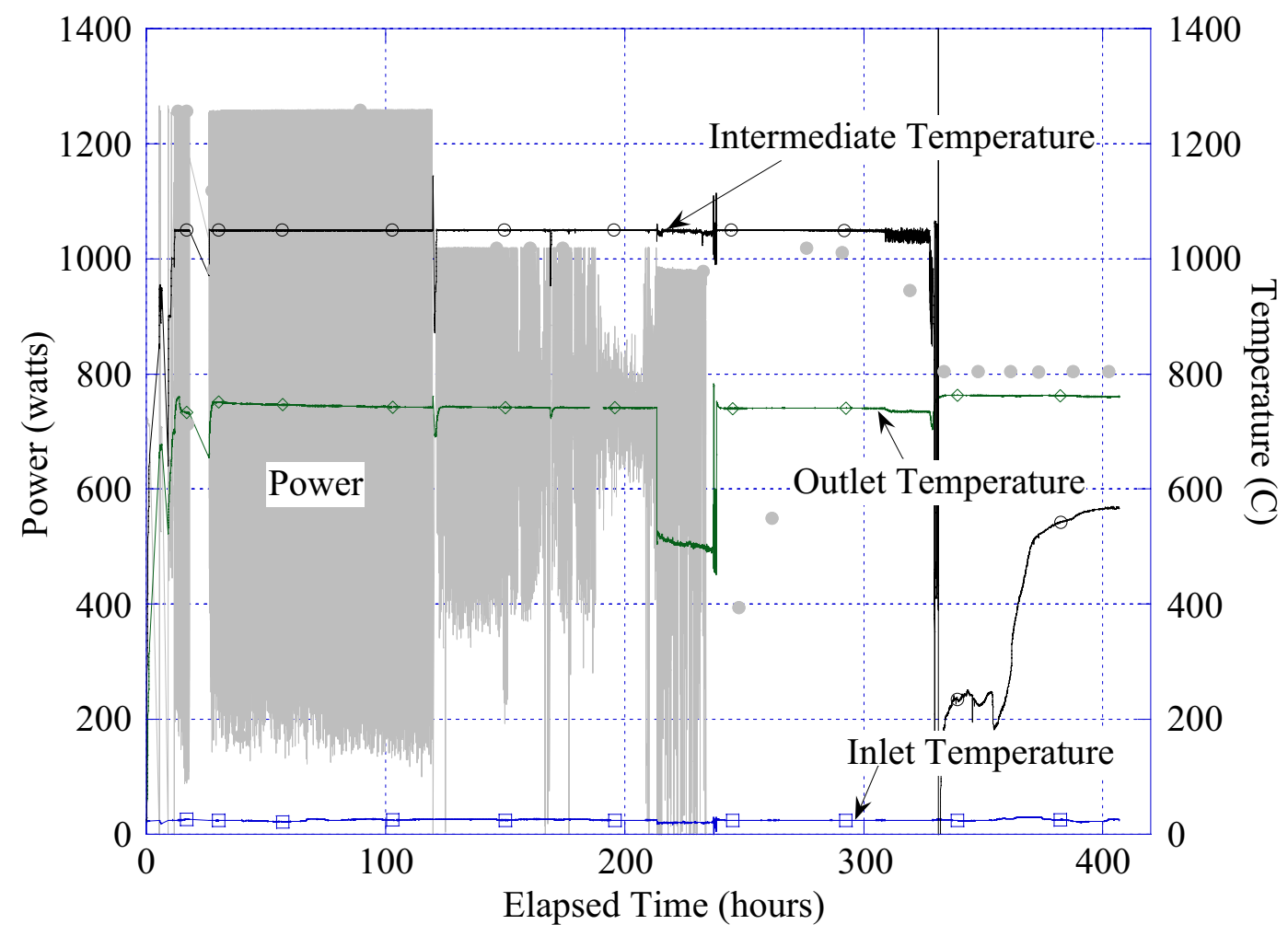

Figure 28. Air superheater performance. 
those recommended for the steam superheater.

\section{CONDENSER}

Observations made during the shakedown test indicated that too much residual water vapor was present in the hydrogen vent line. To improve the condensation, cooling coils made from 1/8 inch copper tubing were wound around the horizontal tube leading from the dew point sensor to the condenser and the vertical condenser outlet tube. In spite of this, a noticeable amount of condensate was still observed in the hydrogen vent line. For the startup experiment, condensate reservoirs were installed both before and after the hydrogen mass flow meter. These reservoirs were drained regularly throughout the course of the experiment.

As noted earlier, a differential pressure transducer was used to track the level in the condensate tank from which the condensate flow rate can be calculated. Fig. 29 shows the tank's condensate volume change for one fill-and-drain cycle.

In order to improve the efficiency of the condenser, the following modifications are suggested:

- Lower the liquid level in the condenser tank so that the entrained water vapor in the hydrogen stream would have more contact with the cold condenser coil in the tank

- Extend the inlet tube so it is the same distance below the condensate level as it is currently

- Increase the length of the vertical outlet tube considerably and surround it with a directcontact cooling sleeve

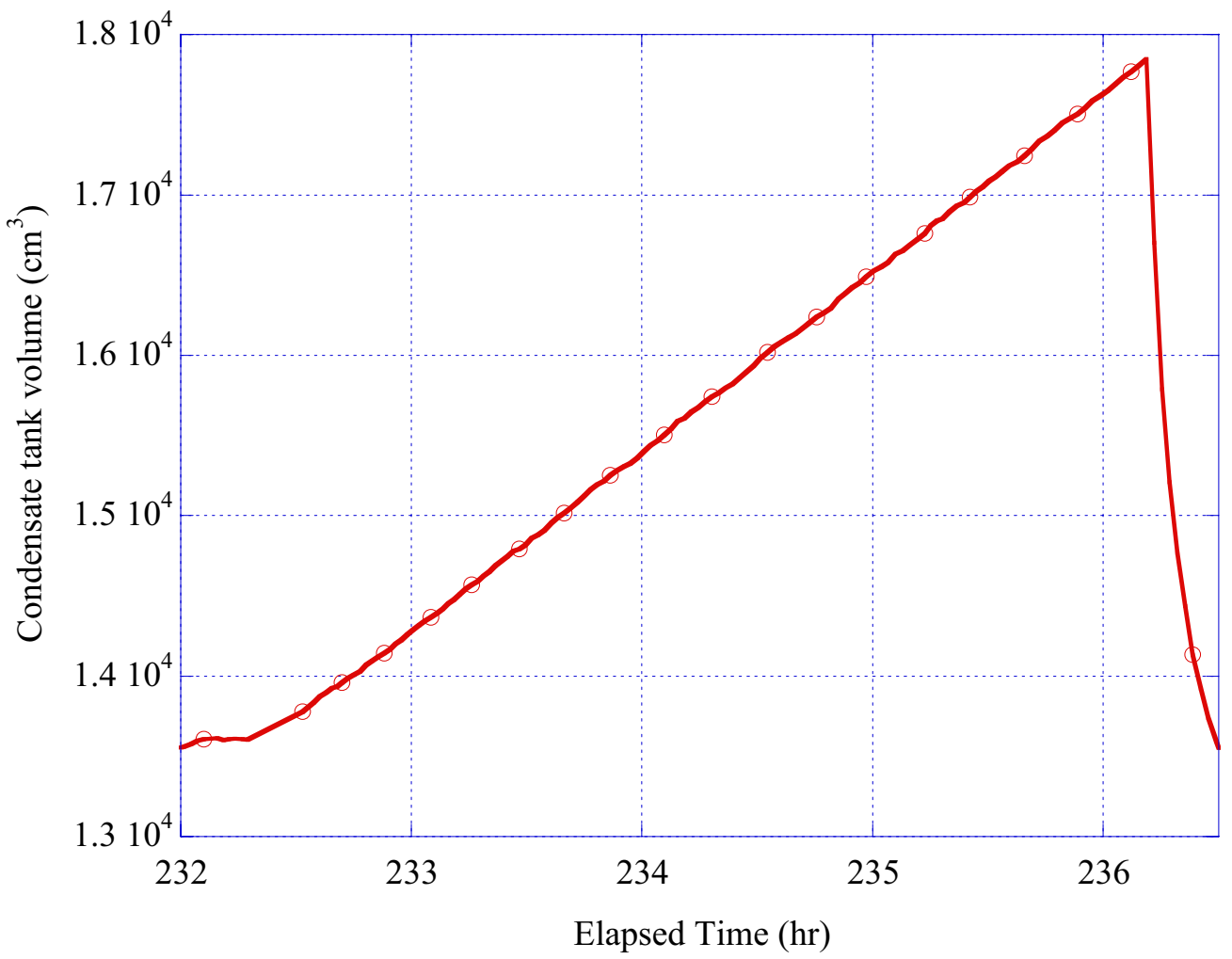

Figure 29. Condensate tank performance. 
- Orient the mass flow meter in a vertical position directly above and in line with the outlet tube so that any condensate can flow directly back into the condenser tank.

\section{DATA ACQUISITION AND CONTROL SYSTEM}

In general, the DACS operated extremely well, despite the complexity of the custom-written LabView virtual instrument. Capabilities of the software include reading and writing to disk 191 channels of data per scan. Screen updates occur approximately every 1.5 seconds. The disk write rate is user-selectable up to the screen update rate. Any data channel(s) can be user-selected and graphed in real time on the computer display. All the power supplies, SCRs, water metering pump, $\mathrm{H}_{2}$ and air flow rates are computer-controlled. The only software problem noted during testing was that the software / computer "locked up" once. The cause for this was never determined, and may have been operator error. At this time, the testing was in steady-state, longduration mode and there was no adverse impact upon the test or module.

Nonetheless, several modifications were made to the DACS during the course of the test. Some of these modifications entailed nothing more than adding displays to the computer display or changing the number of significant digits. Others changes were more involved. One modification already discussed was the inclusion of a computer-controlled relay to engage / disengage the electrolysis power supply.

The most important operational issue concerning the DACS that was discovered during initial testing concerned bias voltages from the module affecting DACS measurements. To prevent future bias voltage problems, intrastack measurements could be made via a separate, smaller data acquisition system.

\section{SUMMARY AND CONCLUSIONS}

Initial shakedown testing of the INL ILS experimental facility commenced on August 22, 2007. The following conditions were met to fulfill a DOE Level 2 milestone:

- The hot zone achieved the electrolysis operating temperature $\left(>800^{\circ} \mathrm{C}\right)$

- The steam generator / superheater combination produced steam at $>800^{\circ} \mathrm{C}$. Air heater produced hot air at $>800^{\circ} \mathrm{C}$.

- A $90 \%$ steam, $10 \% \mathrm{H}_{2}$ mixture at $>800^{\circ} \mathrm{C}$ flowed, at 60 normal liters $/ \mathrm{min}$, and heated air at 23 normal liters per minute, into the Hot Zone and out through the coolers and bubblers. The hot air flowed into the interior of the hot zone. The steam flow rate corresponds to a water flow rate of $40 \mathrm{gm} / \mathrm{min}$.

Heatup of the first ILS module started at approximately 4:10 PM on September 24, 2007. Initial module testing continued for 420 hours. A module polarization curve was generated, which showed that the module performance was lower than the design specification. This lower performance, however, was expected and explained by fabrication difficulties at the subcontractor's facilities. The test-average $\mathrm{H}_{2}$ production rate was approximately $1.3 \mathrm{Nm}^{3} / \mathrm{hr}$, $\left(0.116 \mathrm{~kg} \mathrm{H}_{2} / \mathrm{hr}\right)$ with a peak measured value of over $2 \mathrm{Nm}^{3} / \mathrm{hr}\left(0.179 \mathrm{~kg} \mathrm{H}_{2} / \mathrm{hr}\right)$. Significant module performance degradation was observed over the first 250 hours, after which no further degradation was noted for the remainder of the test. 
Once all test objectives had been successfully met, the test was terminated in a controlled fashion. Several relatively minor problems were encountered during testing, but were resolved without significant impact upon the test. For instance, care must be taken when first introducing steam to the module that the product line temperature is high enough to avoid condensation. These problems, plus the operational experience gained from the test, have identified several modifications that will be incorporated into the facility components to improve reliability and ease of operation for future long-term testing.

\section{REFERENCES}

[1] Stoots, C. M., Condie, K. G., O’Brien, J. E., Housley, G. K., Herring, J. S., "Integrated Laboratory Scale Stack Specification Mechanical Design Report," INL Internal Technical Report, August 15, 2006.

[2] Stoots, C. M., O’Brien, J. E., McKellar, M. G., Hawkes, G. L., and Herring, J. S., "Engineering Process Model for High-Temperature Steam Electrolysis System Performance Evaluation," AIChE 2005 Annual Meeting, Cincinnati, Oct. 30 - Nov. 4, 2005.

[3] O'Brien, J. E., Stoots, C. M., and Hawkes, G. L., "Comparison of a One-Dimensional Model of a High-Temperature Solid-Oxide Electrolysis Stack with CFD and Experimental Results," Proceedings of 2005 ASME International Mechanical Engineering Congress and Exposition IMECE2005, Orlando, Florida, November 5-11, 2005. 